\title{
Palaeocene-Eocene deep water agglutinated foraminifera from the Numidian Flysch (Rif, Northern Morocco): their significance for the palaeoceanography of the Gibraltar gateway
}

\author{
MICHAEL A. KAMINSKI ${ }^{i}$, WOLFGANG KUHNT ${ }^{2}$ \& JON D. RADLEY ${ }^{2}$ \\ 'Research School of Geological and Geophysical Sciences, Birkbeck College and University College London, Gower \\ Street, London WCIE 6BT, UK. \\ Geologisch-Paläontologisches Institut, Christian-Albrechts-Universität Kiel, Olshausenstr. 40, D-24118 Kiel, Germany. \\ "Museum of Isle of Wight Geology, High Street, Sandown, Isle of Wight, PO36 8AF, UK.
}

\begin{abstract}
A lower bathyal to abyssal agglutinated foraminiferal fauna (over 78 taxa belonging 10 31 genera) is documented from Palaeocene-Eocene deep-water sediments of the Numidian Flysch (Talaa Lakrah Unit) in Northern Moroces. The sample locality is adjacent to the Strait of Gibraltar, which comprised an oceanic 'gateway' between the Tethys Occan and the North Atlantic during the Palaeogene. The chronostratigraphy of the section is based upon long-distance comparisons with the stratigraphic ranges of identified species in the North Atlantic region and the Polish Carpathians. Although no major evolutionary turnover among deep-water agglutinated foraminifera (DWAF) is observed across the Palaeocenc/Eocene boundary, a change from Palaeocene Aschemocella- and Trochamminoides-dominated assemblages to an early Eocene Glomospira assemblage is recognized. This Glomospira biofacies occurs throughout the North Atlantic and western Tethys and may indicate lowered productivity and widespread oxygenated deep-water conditions during the early Eocene greenhouse conditions. A change to an overlying Reticulophragmium amplectens biofacies in green claystones reflects renewed higher productivity. Taxonomic affinities and the succession of benthic foraminiferal assemblages from the Gibraltar gateway display greater affinities to Tethyan assemblages than North Atlantic assemblages. This is interpreted as faunal evidence for a late Palaeocene to early Eocene equivalent of 'Mediterranean outflow water', flowing from the western Tethys into the Atlantic. J. Micropalaeontol. 15(1): 1-19. April 1996.
\end{abstract}

\section{INTRODUCTION}

The Palaeocene/Eocene boundary witnessed the greatest turnover in the taxonomic composition of deep-water benthic foraminiferal faunas of any time during the last 80 million years. At this time, the last of the typically Cretaceous benthic foraminifera became extinct, and the new deep-sea faunas of the Eocene migrated down into the ocean basins from the continental margins (Berggren \& Olsson, 1986). Unfortunately, few continuous oceanic Palaeocene-Eocene records with deep-water agglutinated foraminifers (DWAF) are available from the North Atlantic area. In the northeastern North Atlantic, lithofacies changes associated with the Thulean volcanism and the onset of biosiliceous sedimentation render the sediments unfavourable for foraminiferal preservation, and many of the exposed sediments in passive margin settings in the Atlantic area are complicated by sequence boundaries.

One of the few land sections containing well-preserved assemblages of DWAF across the Palaeocene/Eocene boundary is in the Numidian Talaa Lakrah Flysch of northern Morocco. This series comprises a succession of distal deep-sca turbiditic sediments with thick hemipelagic layers that was deposited within the oceanic gateway between the North Atlantic and the western Tethys. This section enables us to examine faunal changes in a continuous deep-sea setting below the CCD. The main objective of this study is to investigate the nature of the Palaeogene turnover in DWAF in the Talaa Lakrah Flysch and assess their biostratigraphic and palaeoecological significance in light of palaeoceanographic changes that took place in the early Palaeogene.

\section{GEOLOGIC SETTING}

The Moroccan Rif mountain chain is an area of complex geology, characterized by numerous sub-basins and troughs that were folded and overthrusted during the Miocene collision of the African and Iberian plates and an intermediate Alboran microplate. Deep ocean sediments are mainly preserved in the 'flysch nappes' of the External Rif Zone, which was originally situated between the Alboran Block and the North African continental margin. Five different facial-tectonic units are distinguished (DurandDelga, 1972; Suter, 1980; Wildi, 1983): (1) the Predorsalian Unit formed by the continental margin sediments of the Alboran microcontinent; (2) the Mauretanian Flysch Unit, deposited in a deep trench adjacent to the Alboran Block: (3) the Massylian Flysch Unit, which represents the basinal sedimentation of the ocean gateway between North Africa and Alboran/Iberia. The Massylian Flysch is generally restricted to the Cretaceous; (4) the Numidian Flysch Unit, situated in a similar palaeogeographic position relative to the Massylian Flysch, but which may overlap with the Mauretanian and Tellian sequences. The Numidian Flysch is comprised of uppermost Cretaceous, Palacogene and Miocene deep water turbidite sequences: (5) the Tellian deep water sediments deposited adjacent to the North African continental margin. 
We sampled a continuous section within the lower part of the Numidian Flysch sequence in a Numidian subunit known as the Talaa Lakrah Flysch. The Talaa Lakrah Flysch Unit was first defined by Didon et al. (1973), based on the Miocene turbiditic sandstone unit exposed in the Strait of Gibraltar on the northern coast of Morocco approximately $18 \mathrm{~km}$ ENE of Tangier, near the village of Talaa Lakrah (Fig. 1). The unit consists of Campanian to Miocene deep-water sediments, and has been included in the Numidian Flysch, which is a geographically widespread unit extending from Sicily along the coast of North Africa to the Strait of Gibraltar. The Numidian Flysch represents the compressional phase of tectonics between the North African and European continents. The flysch unit is overthrust onto Cretaceous deep-water sequences that were probably based on oceanic substratum. The sediments comprising the Numidian Flysch are generally believed to be derived from the North African continent. However, a part of the detrital input to the Talaa Lakrah Unit may have been derived from the Alboran microplate.

The outcrop of the Palaeogene portion of the Talaa Lakrah Unit sampled in this study is situated above a retaining wall behind a Moroccan military outpost, immediately west of the mouth of the Lediane valley. The section is overturned, and consists of steeply dipping turbidite sandstones and interbedded claystones. The base of the sampled section is identified by a c. $1 \mathrm{~m}$ thick sandstone ledge, overlain by dark bluish-grey, tectonically disturbed claystones. The sandstones in the sequence thin upwards, and the sand/shale ratio decreases. The colour of the hemipelagic claystones changes from bluish-grey at the base to reddish-brown, and then to greenish-grey at the top. The colour changes may reflect changing oxygenation of the bottom waters and sediment surface rather than sediment input, and invites comparisons to the coeval oceanic sequences of the North Atlantic.

\section{MATERIAL AND METHODS}

Fifteen large samples (Table 1) were collected from the Talaa Lakrah outcrop (Fig. 2). Samples were dried, weighed, and disaggregated by repeated boiling and drying using sodium carbonate solution. Samples were washed over a $63 \mu \mathrm{m}$ screen. All foraminifera from the $>125 \mu \mathrm{m}$ fraction were picked and mounted onto cardboard microscope slides. In this material, the $63-125 \mu \mathrm{m}$ fraction did not yield identifiable foraminifera.

Smear slides were made of each sample, but all samples were barren of nannofossils. The green samples were tested for palynomorphs and found to be barren.

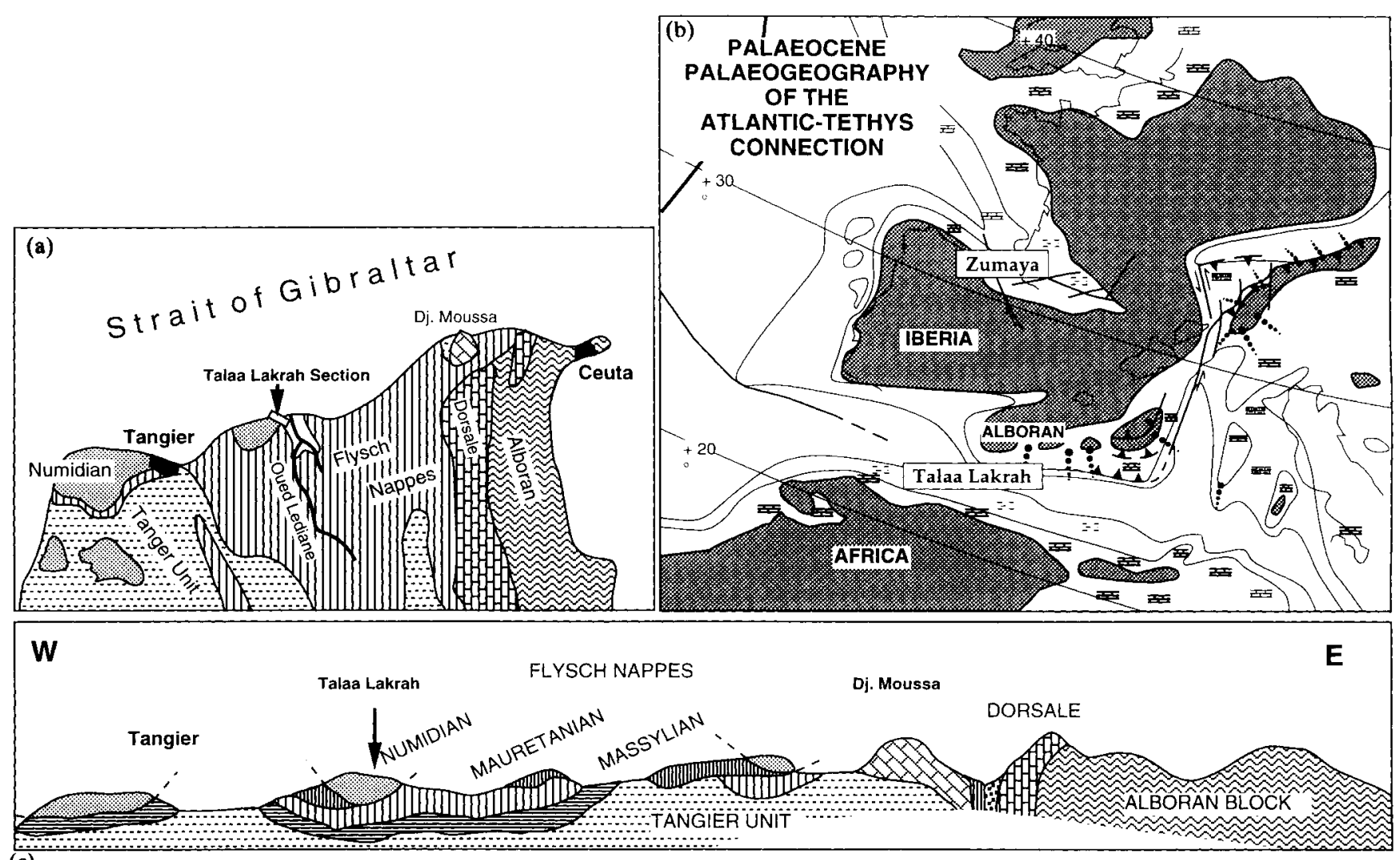

(c)

Fig. 1. (a) Simplified geological map of the Northern Rif (after Didon et al., 1973 and Suter, 1980). (b) Palaeogene palaeogeography of the western Mediterranean (modified after Dercourt et al., 1985) with the position of the sampled locality. (c) Simplified geological cross-section along the Moroccan side of the Strait of Gibraltar (after Didon et al., 1973). 
Palaeocene-Eocene deep water agglutinated forminifera from the Numidian Flysch

\begin{tabular}{lllc}
\hline sample & colour & \multicolumn{1}{c}{ sediment } & $\begin{array}{c}\text { foraminiferal } \\
\text { abundances } \\
\text { individuals/g) }\end{array}$ \\
\hline JDR1 & dark grey & & 0.96 \\
JDR2 & mottled brown-grey-purple & fissile claystone & 0.17 \\
JDR3 & chocolate brown & brittle fissile claystone & 0.54 \\
JDR4 & chocolate brown & fissile claystone & 0.8 \\
JDR5 & chocolate brown & fissile claystone & 0.4 \\
JDR6 & chocolate brown & fissile claystone & 0.48 \\
JDR7 & chocolate brown & fissile claystone & 0.31 \\
JDR8 & gingcr brown & hard fissile claystone & 0.38 \\
JDR9 & ginger brown & fissile claystone & 0.05 \\
JDR10 & brown-purple & fissile claystone & 0.14 \\
JDR11 & ginger brown with green reduction spots & highly fissile claystone & 0.07 \\
JDR12 & green & fissile claystone & 0.09 \\
JDR13 & green & fissile claystone & 0.8 \\
JDR14 & ginger brown & friabletofissileclaystone & 0.15 \\
JDR15 & green & friable green mudstone & 0.3 \\
\hline
\end{tabular}

Table 1. Lithologic description, weights, abundance of foraminifera.

\section{BIOSTRATIGRAPHY}

Because the Palaeogene autochthonous claystones were all barren of calcareous nannofossils, and palynomorphs were probably oxidized, the DWAF provide the only stratigraphic control to constrain the age of the sediments. The chronostratigraphy is necessarily based upon long-distance comparisons will the stratigraphic ranges of identified species in the North Atlantic region and the Polish Carpathians (Fig. 3).

The Palaeocene to Eocene benthic foraminiferal biostratigraphy of the North Sea region has been calibrated to the standard chronostratigraphy by the use of dinoflagellate zones (Charnock \& Jones, 1990). In the Zumaya section of northern Spain, the stratigraphic ranges of DWAF are calibrated to planktonic foraminiferal zones in the Palaeocene to lower Eocene (Fig. 3). The DWAF biostratigraphy at Site 647 in the southern Labrador Sea is calibrated by the use of standard nannofossil zones (Kaminski et al., 1989), but this record only extends upward from lower Eocene Zone NP11. Although nearby DSDP Site 112 penetrated into the Palaeocene, the hole was spot-cored, and did not recover the Palaeocene/Eocene boundary (Miller et al., 1982). The biostratigraphy of DWAF in Trinidad was calibrated to the standard, low-latitude planktic foraminiferal zonation by Kaminski et al. (1988). This biostratigraphic scheme was based upon isolated samples from Zones P1c to P8. However, the Palaeocene/Eocene boundary in Trinidad is represented by
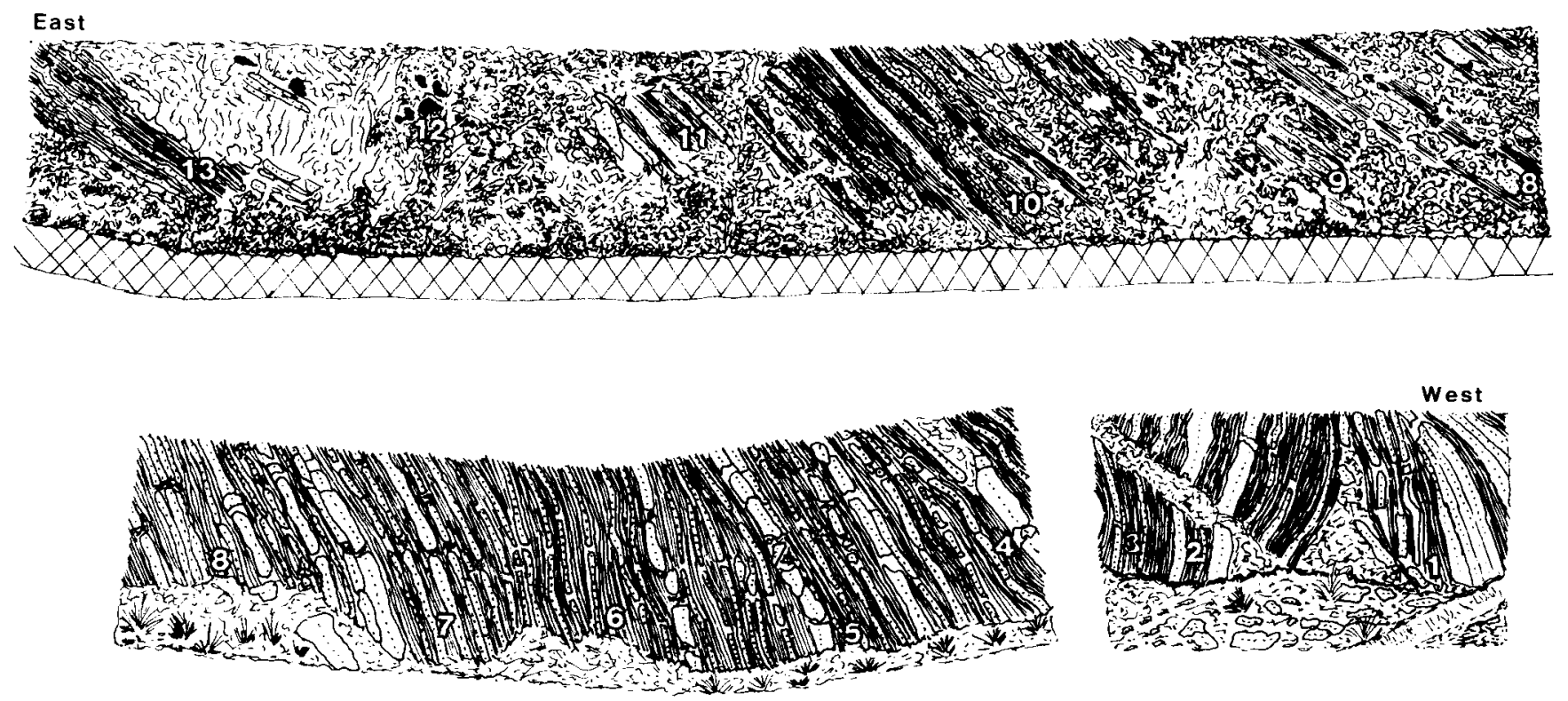

Fig. 2. View of the sampled outcrop at the beach west of the Lediane valley, redrawn from photos. Numbers $1-13$ refer to collected samples. 


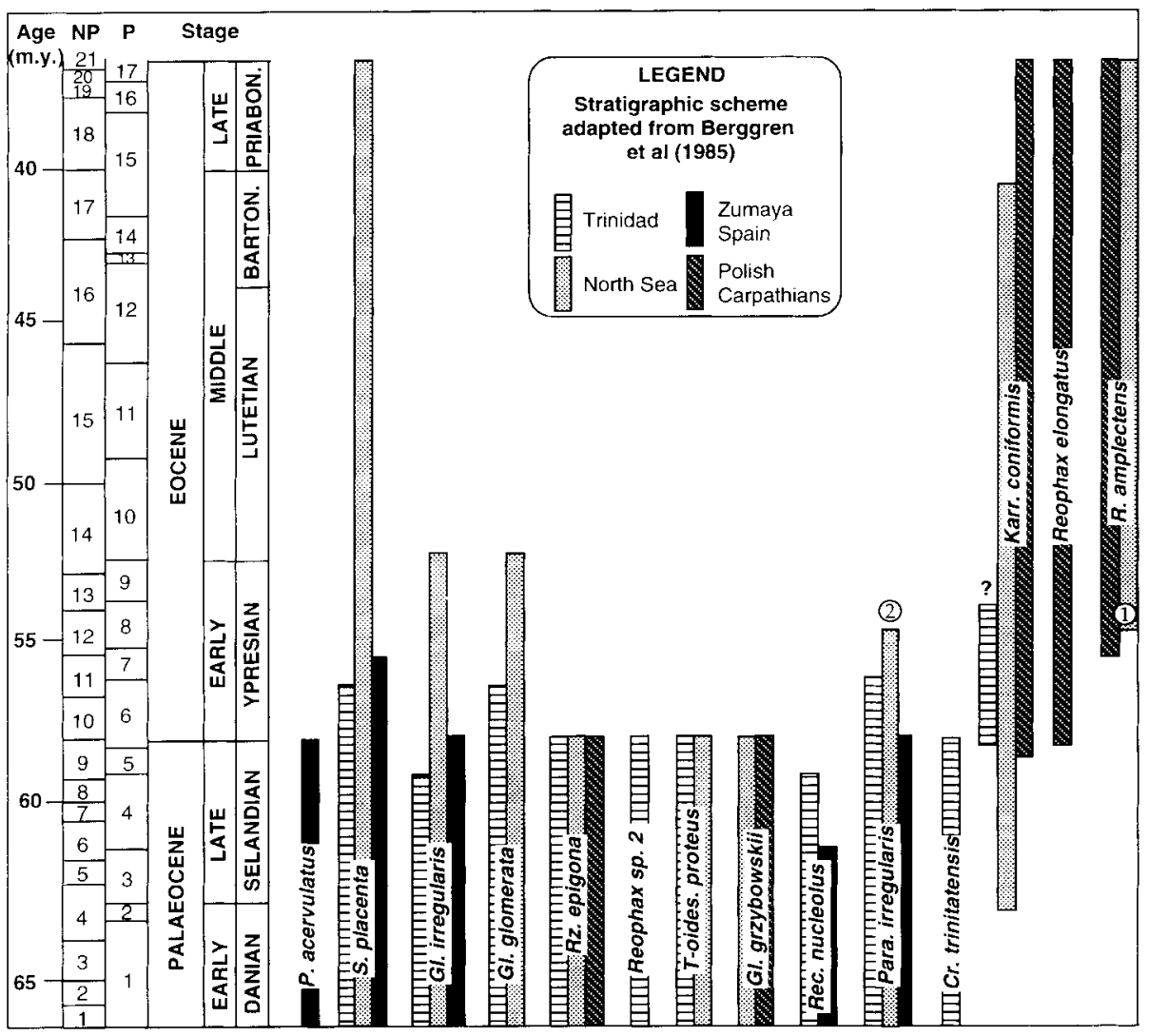

Fig. 3. Ranges of selected Palaeogene DWAF species from the Polish Carpathians (Geroch \& Nowak, 1984), the Basque Basin of northern Spain (Kaminski, 1988). Trinidad (Kaminski et al., 1988), and the North Sea (Charnock \& Jones, 1990). Calibration to planktonic zones applies only to Trinidad and Zumaya. Notes: (1) FO of $R$. amplectens is in Zone P8 in the North Sea (M.A. Charnock, pers. comm., 1994); (2) reported as Conglophragmium coronatum by Charnock \& Jones, 1990.

an unconformity (Bolli, 1957). In the abyssal North Atlantic, Palaeocene claystones are extremely poor in agglutinated foraminifera. Assemblages consist generally of few longranging forms which do not allow any biostratigraphic zonation. Near the Palaeocene/Eocene boundary there is a major change in lithology with lower Eocene sediments becoming increasingly biosiliceous. Normal deep-sea claystones with diverse agglutinated foraminiferal assemblages have been described only from the Labrador and Norwegian Seas (Kaminski et al., 1990).

The Palaeogene DWAF biostratigraphy for the western Tethys is based on the zonation of Geroch \& Nowak (1984). This zonation is based upon composite sections from the Silesian flysch basin in Poland. Because these sediments are largely noncalcareous, direct calibration to the standard plankton zones is not possible, and benthic foraminiferal assemblages were determined based largely on their superposition. The Geroch \& Nowak zonation, while providing an excellent framework for correlation in flysch sediments, is a scheme that still requires direct calibration to the geomagnetic polarity time scale.
The Palaeogene foraminiferal micropalaeontology of the Gibraltar seaway has not been formally described. The only previous micropalaeontological study from the north coast of Morocco is a preliminary note by Morgiel \& Olszewska (1982). In the Talaa Lakrah section, the interval from approximately the middle Palaeocene to middle Eocene is exposed in a continuous stratigraphic succession. In contrast to the Zumaya section which is a shallowing-upward sequence across the Palaeocene/Eocene boundary, the Talaa Lakrah Flysch remains a distal turbidite depositional environment throughout the Palaeogene with a more or less continuous record of hemipelagic deposition (Fig. 4). All the hemipelagic claystones we sampled yielded well-preserved DWAF.

The DWAF assemblages recovered from the Talaa Lakrah samples are generally diverse and show no signs of size sorting. Rare abraded specimens of calcareous benthic foraminifera in Samples 2, 5, 14, and 15 are considered to be redeposited from a shallow bathymetric setting. We recognized a total of 78 species and taxonomic groups in our samples (Table 2), but because a number of our counting 


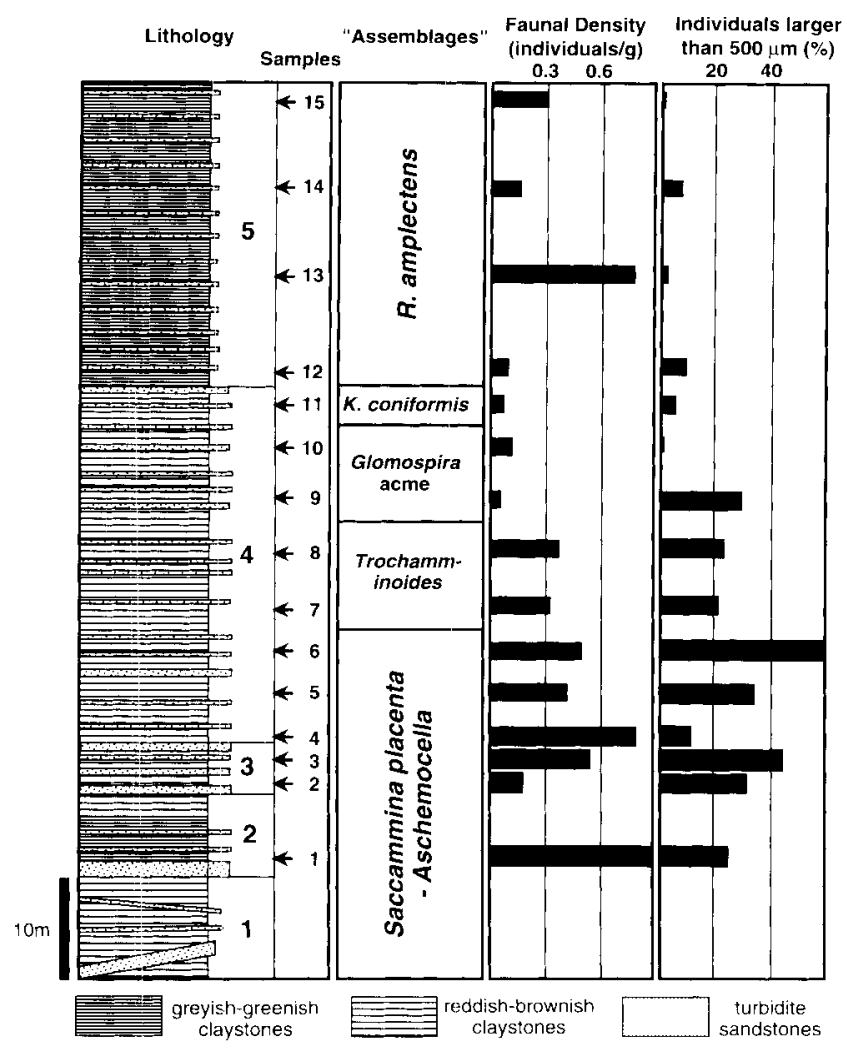

Fig. 4. Simplified lithologic section of the Palacocene-Eocene of the Talaa Lakrah section with the stratigraphic extent of the observed benthic foraminiferal biofacies, and important assemblage parameters

groups include more than one species, our estimates of the faunal diversity must be regarded as a lower limit. Changes in relative percentages of selected species and morphogroups are compiled in Fig. 5.

We discriminate five assemblages within the sampled interval based on the total ranges and relative abundances (Fig. 5) of characteristic species and taxonomic groups:

\section{Aschemocella-Saccammina placenta assemblage}

Samples at the base of the studied section (samples 1-6) are characterized by common occurrence of Aschemocella spp. and Saccammina placenta. The abundance of the former taxon reaches $30 \%$ in sample 6 . Other common forms include species of Rhabdammina and Paratrochamminoides. In the modern deep ocean, tubular taxa are common in turbulent settings affected by deep currents (Kaminski, 1985). The species $A$. carpathica was first described from the upper surfaces of turbidite mudstones in the Romanian Flysch Carpathians (Neagu, 1964). Late Cretaceous Aschemoce'lla-dominated assemblages occur mainly in areas with large amounts of fine-grained detrital supply provided by mud-turbidites. High abundances of Aschemocella may reflect high amounts of organic detritus from terrigenous sources, which provide nutrients for these large taxa.

\section{Trochamminoides/Paratrochamminoides-Recurvoides assemblage}

Samples $7-8$ are dominated by the Paratrochamminoides and Recurvoides groups. Ammodiscids are also significant, but less dominant than in samples 9-14 (see below). The assemblage consists of numerous individuals and species, many of which are yet undescribed. The abundance of diverse Paratrochamminoides in the lower half of the studied section invites comparison to the Upper Cretaceous red clay environments of abyssal turbidite basins (= Flyschtype, high diversity, Paratrochamminoides-faunas of Kuhnt \& Kaminski, 1989). These Late Cretaceous Paratrochamminoides assemblages probably characterized more oligotrophic environments. The Maastrichtian part of the Talaa Lakrah section also contains numerous Paratrochamminoides (Kuhnt \& Kaminski, 1989). Although much of the Palaeocene to lower Eocene part of the Talaa Lakrah section does consist of reddish-brown sediments. there is a significant influence of detrital material.

The taxonomic composition and stratigraphic position of this assemblage is reminiscent of the Trochamminoidesschichten' of Majzon (1943) from the Carpathian flysch. Morgiel \& Olszewska (1981) recognized an acme of Trochamminoides spp. (inc. Paratrochamminoides s.s.) in the Palacocene of the Polish Carpathians. However, Morgiel \& Szymakowska (1978) correlated this acme to the lowermost Eocene. Reddish claystones containing common flattened Pararochamminoides are also known from the lower Eocene Subbotina patagonica Zone (= Zones P7-P8) of the North Sea.

\section{Glomospira-Ammodiscus assemblage}

Samples 9 and 10 contain more than $60 \%$ ammodiscids (Glomospira, Ammodiscus, and Glomospirella). This assemblage correlates with Glomospira-dominated asscmblages observed in other parts of the Atlantic (Kaminski et al., 1989) and western Tethys (Winkler, 1984). The interval is characterized by numerous small specimens of Glomospira spp. and Ammodiscus tenuissimus. A distinctive taxon in this interval is an undescribed species of Glomospira that has very irregular coiling. Our species Glomospira sp. 5 is a form that is probably new, and appears to be related to the Palaeogene species Ammodiscus pennyi.

The faunal abundance and the average size of specimens in this interval diminishes upsection, attaining minimum values in samples 10 and 11 (Fig. 4). This agrees with trends in calcareous benthic assemblages in the lower Eocene of the North Atlantic, which are reported to be depauparate (Berggren \& Olsson, 1986).

\section{Karrerulina coniformis assemblage}

The first occurrence of $K$. coniformis is observed in sample 11. which also contains the maximum abundance of the genus (Fig. 5). In Trinidad the first occurrence (FO) of this species was observed in the lower Eocene (Zone P6b), at Site 647 its FO was observed within Zone NP11, below the Glomospira horizon. The stratigraphic distribution of Karrerulina species may be controlled by palaeoceanog- 


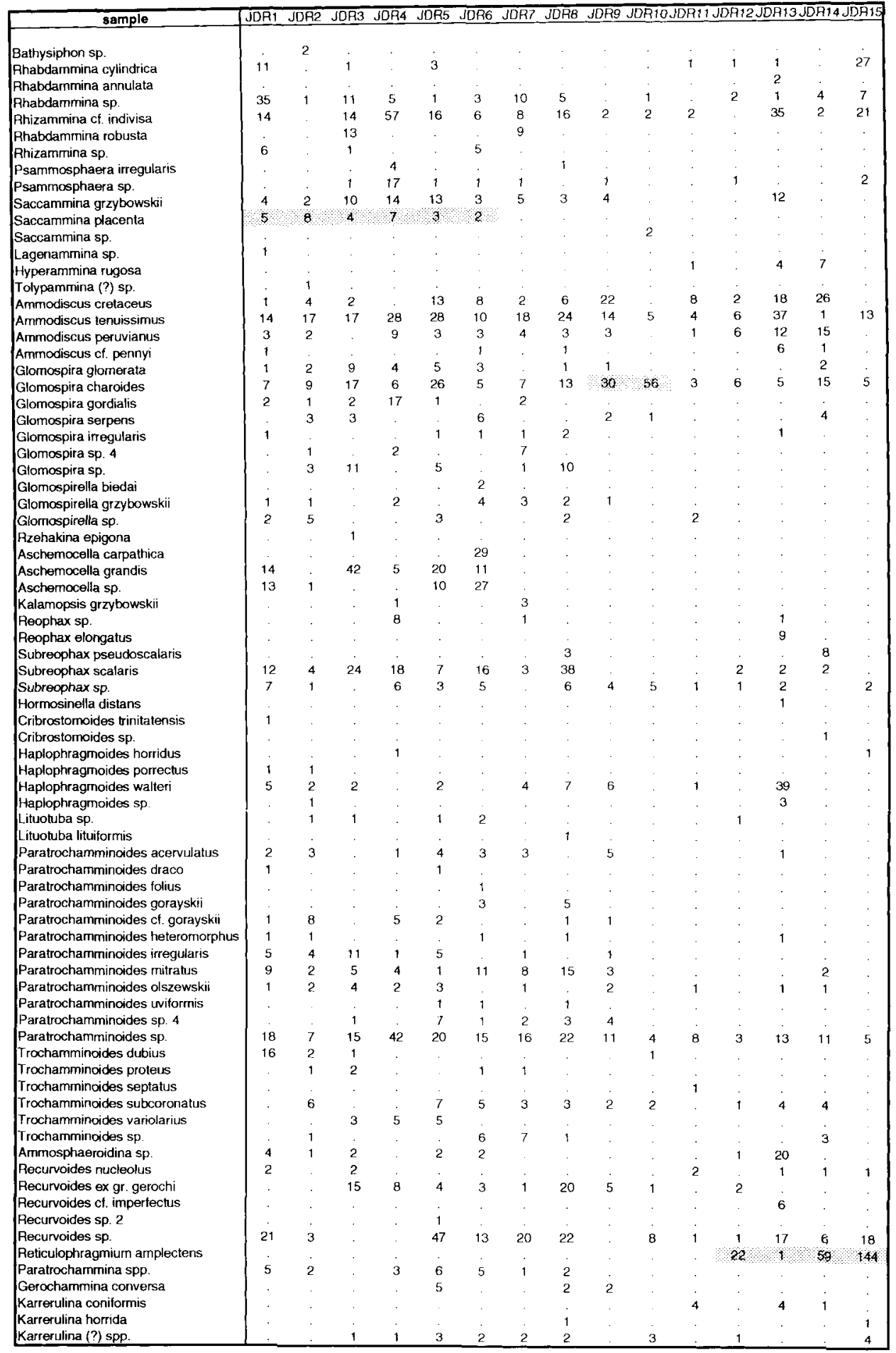

Table 2. Distribution of autochthonous agglutinated foraminifera in the examined samples.

raphic factors such as organic matter flux, since modern representatives of this group live infaunally.

\section{Reticulophragmoides amplectens assemblage}

Samples 12 to 15 are characterized by the common occurrence of $R$. amplectens, which is a typical form of middle to upper Eocene sediments in the Atlantic and western Tethys. Other characteristic forms in the uppermost part of the section are Reophax elongatus and Karrerulina coniformis. Geroch \& Nowak (1984) reported the range of Reophax elongatus as middle to upper Eocene in the Polish Carpathians. The ranges of all of these taxa extend to the Eocene/Oligocene boundary in the North Atlantic (Kaminski et al., 1989). 


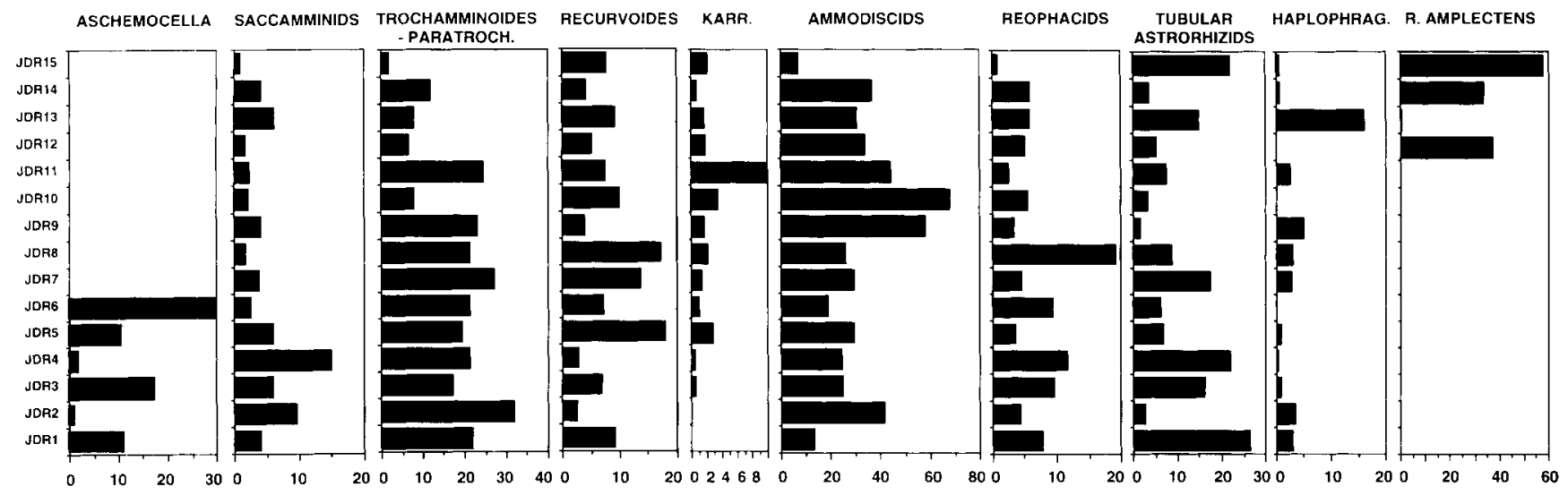

Fig. 5. Relative abundances of selected species and taxonomic groups in the Talaa Lakrah Flysch.

Reticulophragmium amplectens is believed to have evolved from an early Eocene ancestor by the acquisition of additional chambers and advancing the development of alveoles with ontogeny. Jurkiewicz (1967) had already reported that alveolar structure usually begins closer to the proloculus in specimens from younger stratigraphic horizons. Alveoles first appear between the $10^{\text {th }}$ and $17^{\text {th }}$ chamber in the microspheric generation of primitive individuals, and between the $5^{\text {th }}$ and $13^{\text {th }}$ chambers in more advanced individuals. Myatlyuk (1970) considered the smaller early Eocene morphotype of $R$. amplectens with 10 chambers in the last whorl and few alveoles to be a separate species, and named it Cyclammina intermedia. Although lower Eocene assemblages from the North Sea and the Carpathians undoubtedly contain the 'Cyclammina intermedia' morphotype, this form is absent from our samples of the Numidian Flysch. In this regard, they are more similar to early Eocene specimens from Labrador, which consist of "advanced" forms of $R$. amplectens with well-developed alveoles.

\section{FAUNAL, TURNOVER AT THE \\ PALAEOCENE/EOCENE BOUNDARY}

A major turnover of deep-water calcareous benthic foraminiferal taxa at the Palaeocene/Eocene boundary has been observed in all the world's oceans (Tjalsma, 1977; Schnitker. 1979; Tjalsma \& Lohmann, 1983; Thomas \& Shackleton, 1991; Pak \& Miller, 1992). Utilizing benthic foraminiferal oxygen isotope records, Shackleton (1986) suggested that deep oceanic waters had a temperature of approximately $10^{\circ} \mathrm{C}$ in the earliest Palaeogene, increasing to $12^{\circ} \mathrm{C}$ in the early Eocene and then decreasing again. Miller et al. (1987a) suggested that the world ocean was ice-free throughout most of the Palaeocene and Eocene. Their oxygen isotope studies on calcareous benthic foraminifera also indicate rapid warming of sea water from midPalaeocene to early Eocene times, followed by a step-wise deterioration culminating in the late Eocene glaciations. Superimposed on this first-order trend are fluctuations that correspond to rapid climatic change. Kennett \& Stott (1991) documented a rapid c. $8^{\circ} \mathrm{C}$ warming of Antarctic surface waters that coincided with a $4 \%$ drop in foraminiferal $\partial^{1.3} \mathrm{C}$ and the extinction of about half of the calcareous benthic taxa. These authors suggested that deep water circulation was reduced resulting in lowered oxygenation of the deep sca. These isotopic changes have been confirmed in all the occan basins (Stott, 1992), and show that the deep sea warmed to about $10^{\circ} \mathrm{C}$. These unusually warm temperatures persisted for about 100000 years. More importantly, the surface-to-deep foraminiferal $\partial^{13} \mathrm{C}$ gradient decreased from about $1.7 \%$ in the Palaeocene to near zero at Site 690 (Stott, 1992), which suggests that marine organic productivity was severely diminished. This observation corroborates the findings of Miller et al. (1987b) who noted decreased sediment grain size in the Pacific, which implies weaker trade winds and consequently reduced upwelling. The Palaeocene/Eocene warming has been attributed to increased supply of $\mathrm{CO}_{2}$, as a consequence of global tectonic activity (e.g. opening of the Norwegian-Greenland Sea) and volcanism in the North Atlantic region (Owen \& Rea, 1985).

The impact of climatic changes at the Palaeocene/Eocene $(\mathrm{P} / \mathrm{E})$ boundary on DWAF is still poorly documented. While all DWAF localities studied so far display a reduction in both abundance and taxonomic diversity from the upper Palaeocene to the lower Eocene, this turnover cannot be attributed to a single environmental cause (Kaminski, 1991). The bathyal foraminiferal assemblages of Zumaya Spain and the West Greenland, Labrador, and Norwegian continental shelves occur in shallowing-upward sequences. In these areas, Palaeocene agglutinated faunas are replaced by calcareous assemblages, or barren intervals. In the North Sca and Norwegian Sea regions, the boundary is contained within volcanoclastic sediments. In the central North Atlantic the $\mathrm{P} / \mathrm{E}$ boundary occurs within a lithologic change from claystones to radiolarites that are barren of foraminifera. Biostratigraphic data from the upper Maastrichtian to middle Eocene Gurnigel-Schlieren flysch of Switzerland (Winkler, 1984) reveal the last occurrences of six species of DWAF at or just below the P/E boundary. No taxa with first occurrences near the boundary were recorded. In the Polish External Carpathians (Geroch \& Nowak, 1984), five species have last occurrences approximately at 
the $\mathrm{P} / \mathrm{E}$ boundary and two species have first occurrences just above the boundary. In the Guayaguayare and Lizard Springs Formations of Trinidad 15 species display LOs at or just below the boundary and only one incoming species occurs just above the boundary (Kaminski et al., 1988). The most dramatic faunal turnover of DWAF near the $P / E$ boundary has been observed in the North Sea. As many as 20 species display LOs immediately below the $\mathrm{P} / \mathrm{E}$ boundary and 35 species have FOs just above the boundary (Charnock \& Jones, 1990). However, the effects of local palacoenvironmental change in the North Sea area have probably amplified the magnitude of the faunal change.

At Talaa Lakrah, the following taxa have last occurrences between samples 5 and 9 (broadly coincident with the P/E boundary):

Saccammina placenta

Glomospira gordialis

Glomospira grzybowskii

Glomospira sp. 4

Aschemocella carpathica

Aschemocella grandis

Kalamopsis grzybowskii

Paratrochamminoides draco

Paratrochamminoides gorayskii

Paratrochamminoides irregularis

Paratrochamminoides uviformis

Trochamminoides proteus

Trochamminoides variolarius

The only first occurrences observed in the sample 5-9 interval are Karrerulina horrida and Subreophax pseudoscalaris.

Aschemocella assemblages appear to comprise a statistically independent end-member of Late Cretaceous DWAF assemblages that are typically developed in fine-grained turbidite environments, such as the Maastrichtian flysch of the Carpathians and the lower bathyal turbidite units in the Campo de Gibraltar. In the Talaa Lakrah section, the occurrence of Aschemocella is restricted to samples from the Palaeocene that are associated with thick-bedded sandstones. Their disappearance across the $\mathrm{P} / \mathrm{E}$ boundary may result from reduced amounts of organic detritus from terrigenous sources as well as marine organic productivity.

The majority of first and last occurrences across the P/E boundary in this section are among species that are known from the Palaeocene and Eocene at other localities. At Talaa Lakrah, these constitute local biostratigraphic events. In general, it appears that calcareous-cemented agglutinated taxa were especially prone to extinction at the Palaeocene/Eocene boundary. Therefore, the magnitude of the faunal turnover of agglutinated taxa is more pronounced at the marginal North Atlantic sites and is less important in the Tethyan sites below the CCD.

\section{EARLY-MIDDLE EOCENE GLOMOSPIRA EVENT}

Assemblages with common Ammodiscus and Glomospira have been found in the lower Eocene of the AlpineCarpathian region (Jurkiewicz, 1967; Morgiel \& Szymakowska, 1978; Morgiel \& Olszewska, 1981, 1982) and the Moroccan flysch (Morgiel \& Olszewska, 1982). Winkler
(1984) discovered a level with common Glomospira in the lower part of Zone NP10-NP12 (undifferentiated) in the Schlieren flysch of the Alpine Flysch Zone of Switzerland. In the southern Labrador Sea, Glomospira spp. range throughout the Eocene and basal Oligocene at Site 647, but display a distinct acme in Zones NP13-NP15 (Kaminski et al., 1989). Characteristic species of this assemblage consist of Glomospira irregularis, Glomospira charoides, Ammodiscus cretaceus, Karrerulina coniformis, Trochamminoides spp. and Haplophragmoides walteri. At Site 643 in the Norwegian Sea the total range of Glomospira spp. is confined to the lower Eocene (Kaminski et al., 1990). The so-called 'Glomospira Event' is consequently of biostratigraphic use in the North Atlantic and western Tethys, bearing in mind the observation that it may be diachronous from east to west. In the Tellien Units in northern Morocco, we also observed a lower Eocene biosiliceous lithofacies which may correlate with the Glomospira Event in the Numidian Flysch. Immediately above these biosiliceous sediments are claystones with Reticulophragmoides amplectens.

Kuhnt \& Kaminski (1989) noted increased abundances of ammodiscids, especially the genus Glomospirella, in lower Campanian green claystones reflecting poorly oxygenated benthic conditions in the North Atlantic. This distinct assemblage, termed 'Biofacies B', was subsequently found at different Cretaceous horizons at other deep sea localities such as in the Barremian at ODP Site 765 on the Argo Abyssal Plain (Kaminski et al., 1991). In the lower-middle Eocene at ODP Site 647, an interval with abundant Glomospira is characterized by an increase in deposition of biogenic silica (Bohrmann \& Stein, 1989) and organic carbon (Kaminski et al., 1989), which is consistent with a scenario of increased biogenic productivity. Some modern species of Glomospira appear to be environmentally tolerant, and thrive in environments where oxygen and salinity levels are low. They have the ability to survive on organic-rich substrates, such as in an area of active petroleum seepage in the Gulf of Mexico. Alve (1990) recognized an Ammodiscus? [= Glomospirella] gullmarensis assemblage in temperate water masses in Drammensfjord, southeast Norway, characterized by reduced salinity and very low dissolved oxygen content. Kaminski et al. (1989) speculated that Glomospira feed epifaunally on organic detritus, and was consequently well-adapted to areas of high productivity.

However, other aspects of the DWAF assemblages in the Talaa Lakrah section question the validity of this model for the lower Eocene reddish claystones. Both the abundance and relative size of DWAF decline steadily from the Palaeocene, reaching minimum values in the Glomospira acme (Fig. 4). The environmental significance of size and abundance trends in deep-sea benthic foraminifera has been examined by Pederson et al. (1988) and Herguera \& Berger (1991) in their studies of modern and Pleistocene productivity in the Pacific. These studies demonstrated that both the average size of certain benthic foraminifera as well as benthic foraminiferal accumulation rates are positively correlated with the flux of organic matter to the sea floor, and can serve as good proxies for palaeoproductivity. At the 
same time, the relative proportion of tubular forms reaches a minimum (Fig. 5). Because modern tubular taxa such as Rhabdammina and Saccorhiza have been found to be suspension feeders (Altenbach et al., 1988: Linke \& Lutze, 1993), the decline in tubes over this interval may be related to the reduction in food particles carried in suspension by bottom currents. It may simply be the case that Glomospira is an opportunist, inhabiting environments that have undergone rapid change, or occupying niches that have been left vacant by other species.

\section{RETICULOPHRAGMOIDES AMPLECTENS ACME}

Deep-water clastic sediments containing large proportions of Reticulophragmium amplectens are typically referred to the middle Eocene in the Polish Carpathians. In Poland, its first occurrence was reported in the lower Eocene (Zone NP12) by Olszewska \& Smagowicz (1977). Its total range in the Polish Carpathians was given as lower to upper Eocene by Morgiel \& Olszewska (1981), and its partial range and optimum occurrence characterizes the middle Eocene Cyclammina amplectens Zone of Geroch \& Nowak (1984). In the Austrian Alps, $R$. amplectens was reported from the lower to lower middle Eocene Buntmergelserie (Rögl et al, 1986). In the Central North Sea the $R$. amplectens acme is observed immediately above the lower/middle Eocene houndary as determined by palynological and micropalaeontological evidence, occurring in a unit of high gamma ray values (M.A. Charnock, pers. comm., 1994). At Site 647 in the southern Labrador Sea its FO occurs in the upper part of Zone NP11 (below the Glomospira event), and its greatest abundance occurs in the middle Eocene. However. at Talaa Lakrah its first occurrence is above the Glomospira event, which is consistent with its occurrence in the Carpathians.

The palaeoecology of $R$. amplectens is not well understood, however, its symmetrical shape and circular outline recalls that of the modern deep-sea species Melonis barleeanum, a mobile infaunal detritivore (Corliss, 1985). Moreover, $R$. amplectens is one of the dominant taxa in the Eocene of the Labrador margin (beneath the oxygen minimum zone) but only comprises $5-10 \%$ of the assemblage at abyssal Site 647. This agrees with findings of Corliss \& Chen (1988) and Corliss \& Fois (1991), who observed a shift from dominant infaunal taxa in the upper-middle bathyal zone to dominant epifaunal taxa in the lower bathyal to abyssal zone. This changeover is related to the amount of food available to the infauna. If $R$. amplectens was indeed infaunal, then its dominance in the greenish claystones above the Glomospira event indicates a return to the more productive and/or less well oxygenated oceanographic conditions that favour significant proportions of infauna.

\section{PALAEOENVIRONMENT AND PALAEOCEANOGRAPHY OF THE PALAEOGENE NUMIDIAN FLYSCH BASIN}

The Palaeogene of the Talaa Lakrah Flysch is characterized by diverse flysch-type agglutinated foraminifera and a lack of autochthonous calcareous forms. They are interpreted as autochthonous assemblages and can be viewed as remnants of former benthic communities that flourished beneath the CCD.

It is surprising that two otherwise common early Palaeogene species are absent entirely (Spiroplectammina spectabilis) or extremely rare (a single specimen of Rzehakina epigona in sample 3 ) in our material from the Talaa Lakrah Flysch. Spiroplectammina spectabilis and $R$. epigona are among the most common and characteristic species of DWAF in Palaeocene deep-water sediments deposited along the North African continental margin, in Trinidad, and in the Central North Sea. Both species preferably occur in dark greenish shales with enhanced content of organic carbon and may characterize environments with high organic flux rates. Consequently, the absence of these species at Talaa Lakrah might reflect low abundances of organic matter or other nutrients.

Although the assemblages consist mainly of cosmopolitan species, the relative succession of benthic foraminiferal assemblages from the Gibraltar gateway displays a greater affinities to Tethyan assemblages than to assemblages from the North Atlantic. In particular the presence of an assemblage consisting of diverse species of Paratrochamminoides and Trochamminoides overlain by a Glomospira-dominated assemblage provides evidence of strong links with the Carpathian Palaeocene-Eocene deposits. This gives us some insight into the nature of the deep water masses. For example, studies of carbon isotopes (Katz \& Miller, 1991) have revealed that the Southern ocean was a source of deep water during the late Palaeocene and again during the early Eocene, but that the supply of deep water decreased near the Palaeocene/Eocene boundary. This interpretation is supported by the observation of a late Palaeocene erosional hiatus on the Bermuda Rise, indicating strong bottom currents flowing into the North Atlantic from the south (Mountain \& Miller, 1992). Sediment deposition resumed on the Bermuda Rise during the latest Palaeocene, a result of the reduction in deep-water circulation. General ocean circulation models have suggested that the eastern Tethys was a likely zone of high evaporation and therefore a prime site for the formation of warm, saline deep water (WSDW) (Barron \& Peterson, 1990). It is possible that the change in the oxidation state of the sediments at Talaa Lakrah and the loss of large specimens is a reflection of differing bottom water sources. We suggest that the appearance of lower Eocene reddish shales reflects a proximal WSDW source which was well oxygenated and nutrient depleted.

The abrupt appearance of an $R$. amplectens dominated assemblage above the Glomospira event horizon may have palaeoceanographic significance. At DSDP Site 401 in the Bay of Biscay, Pak \& Miller (1992) noted a change from an earliest Eocene Nuttalides truempyi assemblage to an assemblage dominated by Buliminella grata, Stilostomella gracillima and Bulimina semicostata in Zone P6c. In Zones P8-P9 Stilostomella (an infaunal form) was dominant. This shift from epifaunal-dominated assemblages to ones dominated by infauna in the middle part of the early Eocene also points to similar changes in oxygenation and/or 
palaeoproductivity. Because the Bay of Biscay is distal to any proto-Mediterranean outflow water flowing northward around Portugal as an eastern boundary current, perhaps the assemblage changes in the Gibraltar and Biscay regions are linked. Indeed, based on their comparison of stable isotopic data, Pak \& Miller believed that Site 401 monitored deep water of a western Tethyan origin.

\section{CONCLUSIONS}

The diverse (>78 taxa) DWAF assemblages of the Talaa Lakrah Flysch compare well with the diverse cosmopolitan flysch-type agglutinated assemblages in the sense of Gradstein \& Berggren (1981). The depositional environment of the Palaeogene Talaa Lakrah turbidites was lower bathyal or abyssal, and below the calcium carbonate compensation depth.

The taxonomic affinities and relative succession of benthic foraminiferal assemblages from the Gibraltar gateway are more Tethyan than Atlantic. In particular, diverse Paratrochamminoides and Trochamminoides and the presence of an interval of reddish claystones with Glomospira provide strong links with the Palaeocene-Eocene assemblages of the Carpathians. We interpret this as faunal evidence for a late Palaeocene to early Eocene equivalent of 'Mediterranean outflow water', with bottom water flowing from the western Tethys into the Atlantic as it does today.

Despite the now well-documented Palaeocene/Eocene boundary extinction event among calcareous benthic foraminifera, there is surprisingly little taxonomic turnover among DWAF in the Talaa Lakrah section (in terms of species extinctions and originations). However, changes in the size, abundance, and relative proportions of agglutinated foraminifera across the Palaeocene/Eocene boundary interval undoubtedly reflect environmental changes that took place in the western Tethys. Reductions in the abundance and size of DWAF from the Palaeocene to the lower Eocene indicate decreasing nutrients and/or palaeoproductivity. An early Eocene Glomospira-dominated biofacies can be attributed to a period of well-oxygenated, oligotrophic conditions, probably caused by reduced particulate organic matter flux. The sparse assemblages from oxygenated sediments may be linked to lowered surface water productivity during the early Eocene climatic optimum and/or warm, well-oxygenated deep water masses of possible Tethyan origin. The return to greenish-grey, biosiliceous claystones with successive Karrerulinadominated and $R$. amplectens-dominated assemblages signalled the return to a more eutrophic environment.

\section{TAXONOMIC NOTES}

Because of the current need for revision of the suprageneric classification of the agglutinated foraminifera, the taxa below are simply listed alphabetically by genus. For the sake of brevity, only primary references and revisions of primary types are cited.

Ammodiscus cretaceus (Reuss, 1845)

(Pl. 1, figs 1-2)

1845 Operculina cretacea Reuss: 35 , pl. 13, figs 64, 65

Ammodiscus cfi. pennyi Cushman \& Jarvis, 1928

1928 Ammodiscus pennyi Cushman \& Jarvis: 87, pl. 12, figs 4-5

Ammodiscus peruvianus Berry, 1928

(Pl. 1, fig. 3)

1928 Ammodiscus pertwianus Berry: 342, pl. 27

Ammodiscus tenuissimus Grzybowski, 1898

(Pl. 1, fig. 4)

1898 Ammodiscus tenuissimus Grzybowski: 282, pl. 10, fig. 35

Ammosphaeroidina sp.

(Pl. 2, fig. 15)

Aschemocella carpathica (Ncagu, 1964)

(Pl. 2, fig. 3)

1964 Aschemonella carpathica Neagu: 582, text-fig. 1/5-8, 2/2-4. $3 / 1-3,4 / 166$, pl. 27 , figs $1-3$

Aschemocella grandis (Grzybowski, 1898)

(Pl. 2, fig. 4)

1898 Reophax grandis Grzybowski: 277, pl. 10, figs 13-15

1993 Aschemocella grandis (Grzybowski): Kaminski \& Geroch: 249. pl. 2, figs $8-10$

Bathysiphon sp.

Fragments of elongate cylindrical tubes, thin walled and finely agglutinated.

Cribrostomoides trinitatensis Cushman \& Jarvis, 1928

(Pl. 2, fig. 14)

1928 Cribrostomoides trinitatensis Cushman \& Jarvis: 21, pl. 12, figs $12 \mathrm{a}-\mathrm{b}$

Glomospira charoides (Jones \& Parker, 1860)

(PI. 1, fig. 12)

1860 Trochammina squamata Jones \& Parker var. charoides Jones \& Parker: 304

1990 Glomospira charoides (Jones \& Parker); Berggren \& Kaminski: 60, pl. 1, fig. 2

Glomospira glomerata (Grzybowski, 1898)

(Pl. 1, fig. 13)

1898 Ammodiscus glomeratus Grzybowski: 285, pl. 11, fig. 4

Glomospira gordialis (Jones \& Parker, 1860)

(Pl. 1. fig. 14)

1860 Trochammina squamata Jones \& Parker var. gordialis Jones \& Parker, p. 304

1990 Glomospira gordialis (Jones \& Parker); Berggren \& Kaminski: pl. 1, fig. 1

Glomospira irregularis (Grzybowski, 1898)

(Pl. 1, fig. 9)

1898 Ammodiscus irregularis Grzybowski: 285, pl. 11, figs 2, 3

1993 Glomospira irregularis (Grzybowski); Kaminski \& Geroch: 256. pl. 6, figs $6-8 b$

\section{Explanation of Plate 1}

Figs. 1-2, Ammodiscus cretaceus (Reuss), Sample 5. Fig. 1: $\times 69$, Fig. 2: $\times 37$. Fig. 3, Ammodiscus peruvianus Berry. Sample 9, $\times 55$. Fig. 4, Ammodiscus tenuissimus Grzybowski, Sample 6, $\times 66$. Figs. 5-8, Glomospira sp. 5, Fig. 5: Sample $6 \times 22$, Fig. 6: Sample $3 \times 18$, Fig. 7: Sample 1 $\times 13$, Fig. 8: Sample $7 \times 35$. Fig. 9, Glomospira irregularis Grzybowski, Sample $2, \times 125$. Figs. 10-11, Glomospirella biedai Samuel, Fig. 10: Sample 7, $\times 35$, Fig. 11: Sample 6, ×37. Fig. 12, Glomospira charoides (Jones \& Parker), Sample 10, ×69. Fig. 13, Glomospira glomerata (Grzybowski), Sample 6, ×16. Fig. 14, Glomospira gordialis (Jones \& Parker), Sample 9, $\times 69$. Fig. 15, Glomospira serpens (Grzybowski), Sample 3, ×55. Fig. 16, Rzehakina epigona (Rzehak), Sample 3, $\times 69$. 


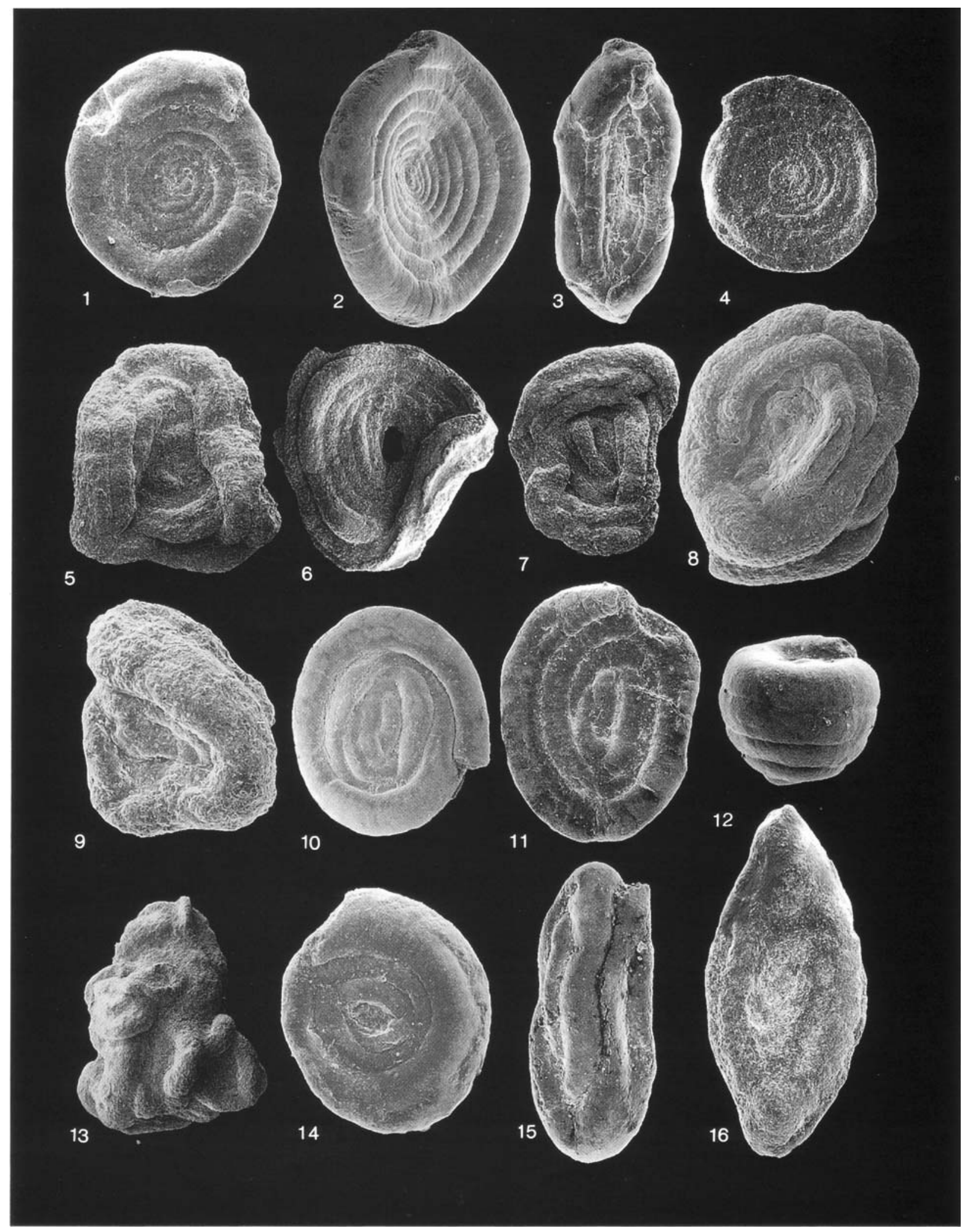

Plate 1 
Glomospira serpens (Grzybowski, 1898)

(P1. 1, fig. 15)

1898 Ammodiscus serpens Grzybowski: 285, pl. 10, figs 31-33 1993 Glomospira serpens (Grzybowski); Kaminski \& Geroch: 256. pl. 6. figs. $2-5$

Glomospira sp. 5

(Pl. 1, figs 5-8)

Medium to large-sized test, arranged in planispiral to irregularly glomospiral coils. Test wall thick, and relatively coarsely agglutinated. Although the test may be large, the chamber increases in diameter slowly and does not become more irregular with ontogeny, as in some other species of Glomospira. Differs from Ammodiscus pennyi in its irregularly glomospiral coiling. Glomospira irregularis differs in its more enrolled streptospiral coiling.

Glomospirella biedai Samuel, 1977

(PI. 1, fig. 11)

1977 Glomospirella biedai Samuel: 29, pl. 3, fig. 16: pl. 21, fig. 3

Glomospirella grzybowskii (Jurkiewič, 1960)

(PI. 1, fig. 10)

1960 Glomospira grzybowskii Jurkiewicz: 342, pl. 38, figs 7, 10, 11

Haplophragmoides horridus (Grzybowski, 1901)

1901 Haplophragmium horridum Grzybowski: 270-271, pl. 7, fig. 12 1993 Haplophragmoides horridus (Grzybowski); Kaminski \& Gcroch: 275. pl. 15, figs 6-8

Haplophragmoides porrectus Maslakova, 1955

(Pl. 2, fig. 11)

1955 Haplophragmoides porrectus Maslakova: 47, pl. 3, figs 5-6

Haplophragmoides walteri (Grzybowski, 1898)

(Pl. 2, fig. 10)

1898 Trochammina walteri Grzybowski: 290, pl. 11, fig. 31.

1993 Haplophragmoides walteri (Grzybowski); Kaminski \& Geroch:

263. pl. 10, figs $3 \mathrm{a}-7 \mathrm{c}$

Hormosinella distans (Brady, 1881)

(PI. 2, fig. 6)

1881 Reophax distans Brady: 50
Hyperammina rugosa Verdenius \& Van Hinte 1983

(Pl. 1, fig. 7)

1983 Hyperammna rugosa Verdenius \& Van Hinte: 187, pl. 1, figs $12-14$

Kalamopsis grzybowskii (Dylążanka, 1923)

(Pl. 2, fig. 11)

1923 Hyperammina grzvbowskii Dylà[[hungarumlaut]|anka: 65-66

1993 Kalamopsis grybowskii (Dylà[[hungarumlaut]|anka); Kaminski \& Geroch, 281, pl. 17, figs 5a-8

Karrerulina coniformis (Grzybowski, 1898)

1898 Gaudryina coniformis Grzybowski: 295, pl. 12, fig. 7

1993 Karrerulina coniformis (Grzybowski); Kaminski \& Geroch: 269 , pl. 13 , figs $1-4$

Gerochammina conversa (Ġrzybowski, 1901)

(Pl. 2, figs 16)

1901 Gaudryina conversa Grzybowski: 285, pl. 7, figs 15, 16

1993 Gerochammina conversa (Grzybowski); Kaminski \& Geroch: 279, pl. 13, figs 5a-11

Karrerulina horrida Myatlyuk, 1970

(PI. 2, fig. 17)

1970 Karreriella horrida Myatlyuk: 114-115, pl. 5, fig. 9; pl. 33, figs $15-16 \mathrm{c}$

Lagenammina sp.

Lituotuba lituiformis (Brady, 1879)

1879 Trochammina lituiformis Brady: 59, pl. 5, fig. 16

Paratrochammina spp.

We place in the genus Paratrochamminoides all forms with irregular streptospiral, glomospiral, trochospiral, or triloculine coiling (which may uncoil in the later stage) and irregular rounded to elongate chambers. Trochamminoides is distinguished by its irregular planispiral coiling. The family Lituotubidae is in need of revision. Specimens classified here as Paratrochammina spp. are mostly badly preserved and/or fragmentary.

Paratrochamminoides acervulatus (Grzybowski, 1896)

1896 Trochammina acervulata Grzybowski: 284, pl. 9, fig. 4 a-c

1981 Trochammina acervulata Grzybowski: Liszka \& Liszkowa: p.

176, pl. 3, fig. $1 \mathrm{a}-\mathrm{c}$

\section{Explanation of Plate 2}

Figs. 1-2, Saccammina placenta (Grzybowski), Fig. 1: Sample 9, $\times 59$. Fig. 2: Sample $5, \times 33$. Fig. 3, Aschemocella carpathica (Neagu), Sample 3 $\times 9$. Fig. 4, Aschemocella grandis (Grzybowski), Sample $3 \times 8$. Fig. 5, Kalamopsis grzybowskii (Dylążanka), Sample 4, $\times 35$. Fig. 6, Hormosinella distans (Brady), Sample 13, $\times 69$. Figs. 7-8, Reophax elongatus Grzybowski, Sample 13, $\times 35$. Fig. 9, Subreophax scalaris (Grzybowski), Sample 3, $\times 55$. Fig. 10, Haplophragmoides walteri (Grzybowski), Sample 9, $\times 90$. Fig. 11, Haplophragmoides porrectus Maslakova, Sample 1, $\times 95$. Fig. 12, Reticulophragmium amplectens (Grzybowski), Sample 12, $\times 42$. Fig. 13, Recurvoides nucleolus (Grzybowski), Sample 1, $\times 45$. Fig. 14, Cribrostomoides trinitatensis Cushman \& Jarvis, Sample $1, \times 25$. Fig. 15, Ammosphaeroidina sp., Sample 13, $\times 103$. Fig. 16, Gerochammina conversa (Grzybowski), Sample 5, $\times 68$. Fig. 17, Karrerulina horrida Myatlyuk, Sample $8, \times 68$.

\section{Explanation of Plate 3}

Fig. 1, Trochamminoides dubius (Grzybowski), Sample 1, $\times 50$. Fig. 2, Trochamminoides dubius (Grzybowski). Sample 8 , $\times 48$. Fig. 3, Trochamminoides dubius (Grzybowski), Sample 1, $\times 38$. Fig. 4, Trochamminoides dubius (Grzybowski), Sample 3, $\times 38 . \quad$ Fig. 5, Trochamminoides variolarius (Grzybowski), Sample 3, $\times 38$. Fig. 6, Paratrochamminoides uviformis (Grzybowski), Sample 7, $\times 38$. Fig. 7, Trochamminoides subcoronatus (Grzybowski), $\times 27$. Fig. 8, Paratrochamminoides draco (Grzybowski). $\times 26$. Fig. 9, Trochamminoides septatus (Grzybowski), Sample 11, $\times 74$. Fig. 10, Paratrochamminoides sp. 4, Sample 4, $\times 20$. Fig. 11, Paratrochamminoides sp. 4, Sample 5, $\times 18$. Fig. 12, Trochamminoides proteus (Karrer), Sample 5, $\times 26$.

\section{Explanation of Plate 4}

Figs. 1a-2, Paratrochamminoides sp. 5, Sample 8, Fig. 1: $\times 52$, Fig. 2: $\times 36$. Figs. 3-5, Paratrochamminoides heteromorphus $($ Grzybowski), Fig. 3: Sample 1, $\times 40$; Fig. 4: Sample 2, $\times 27$, Fig. 5, Sample 3, $\times 13$. Figs. 6-7, Paratrochamminoides gorayskii (Grzybowski), Fig. 6: Sample 6, $\times 27$, Fig. 7: Sample 4, $\times 72$. Fig. 8, Paratrochamminoides irregularis (White), Sample $5, \times 20$. Fig. 9, Paratrochamminoides mitratus (Grzybowski), Sample 8, $\times 20$. Fig. 10, Paratrochamminoides olszewskii (Grzybowski), Sample $7, \times 38$ 

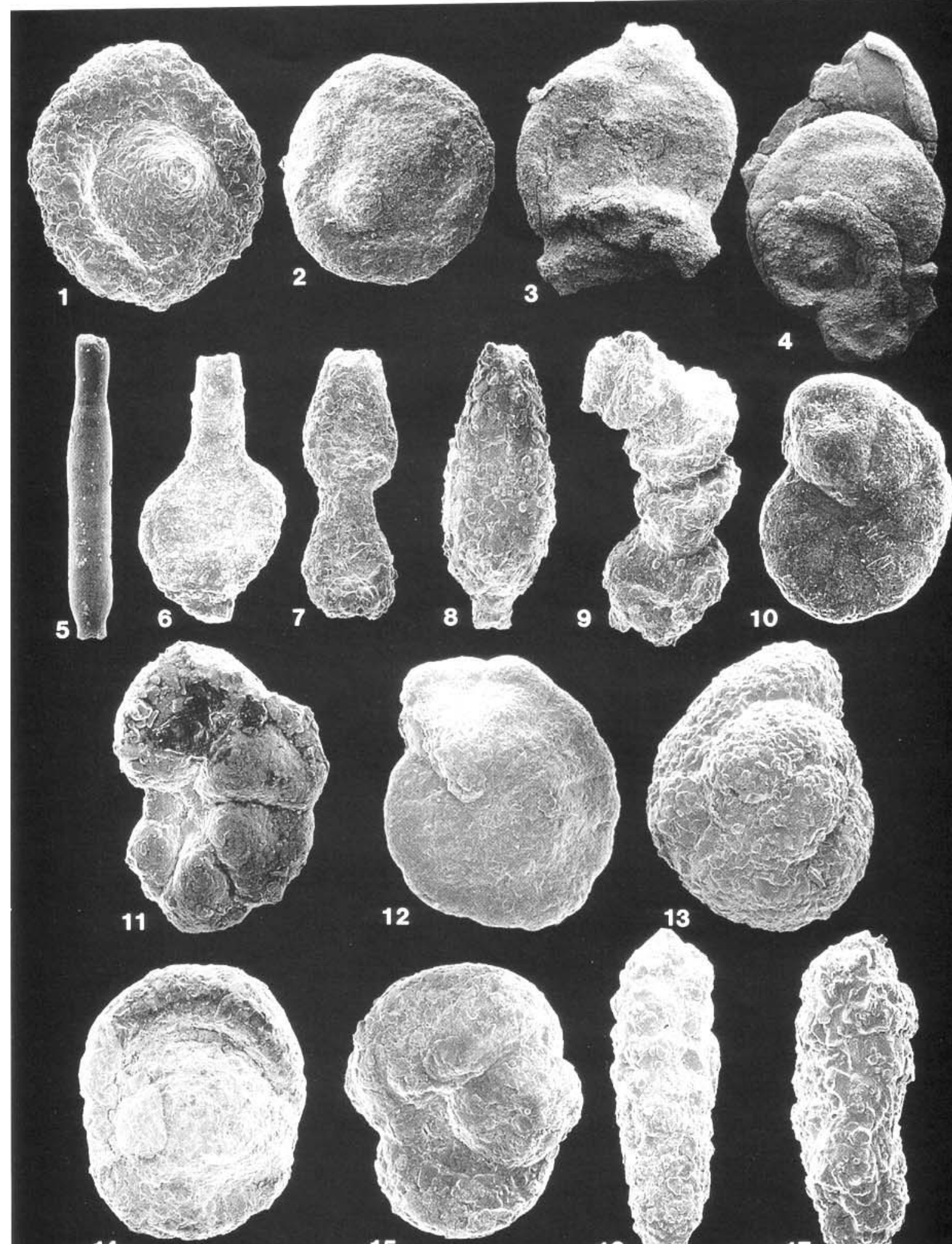

14
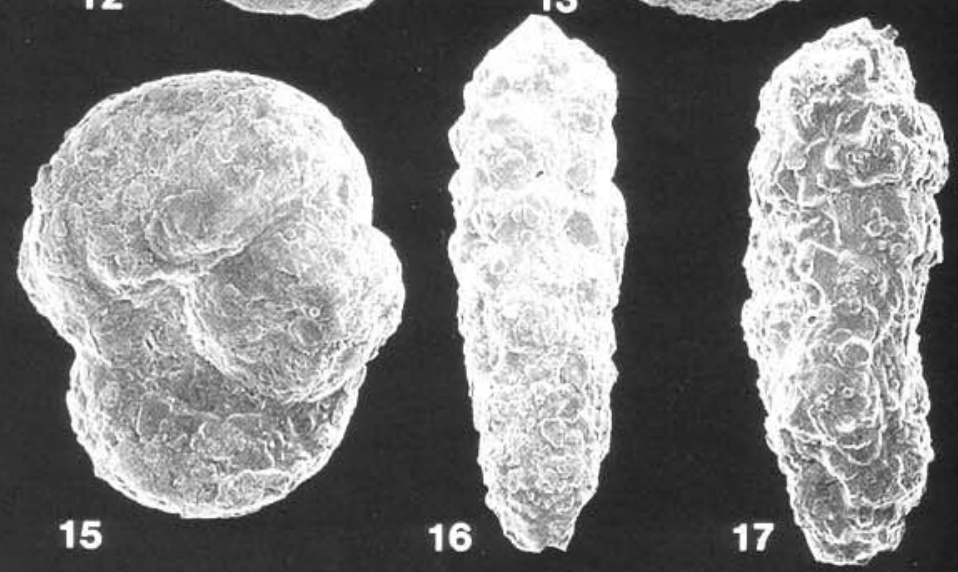

Plate 2 


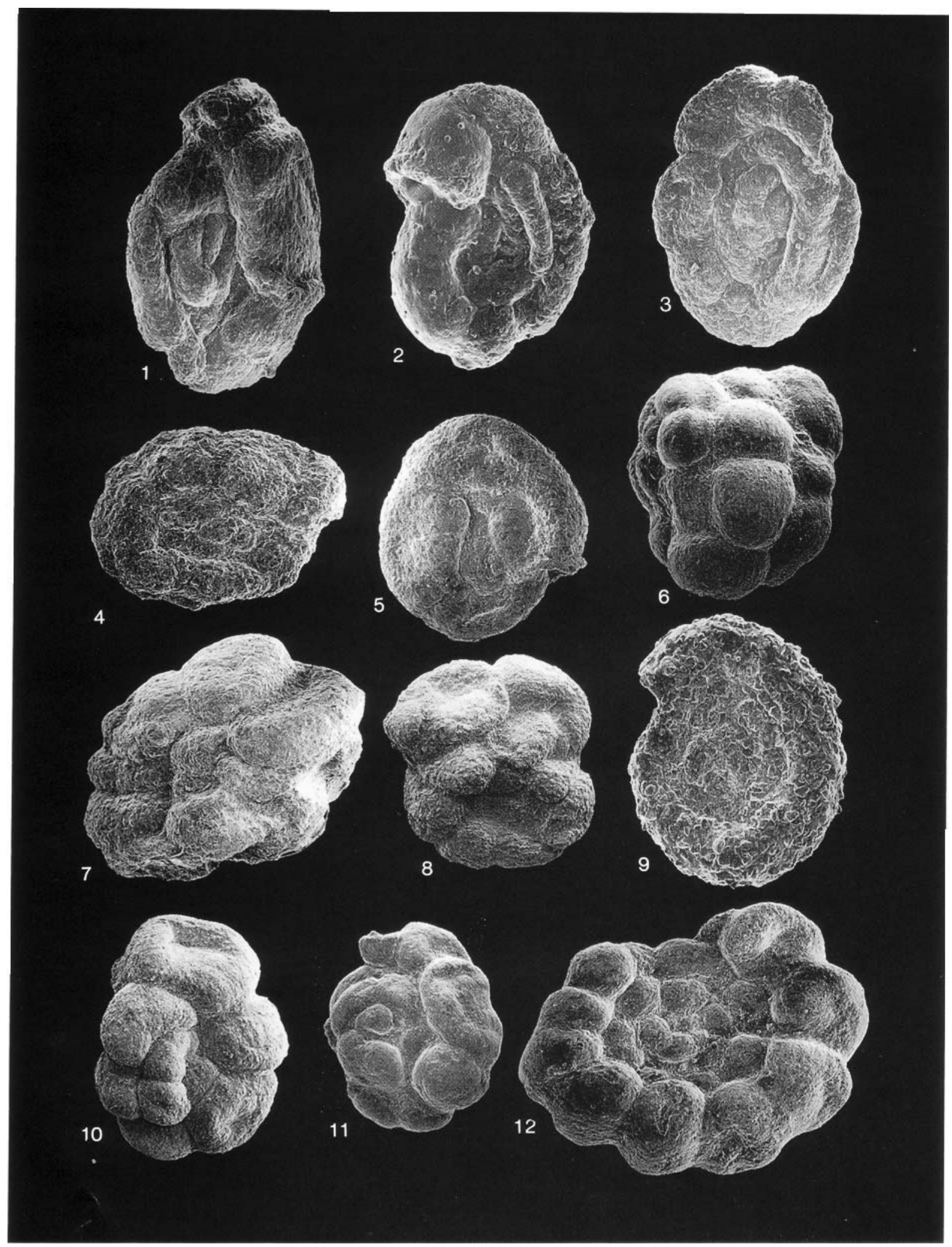

Plate 3 


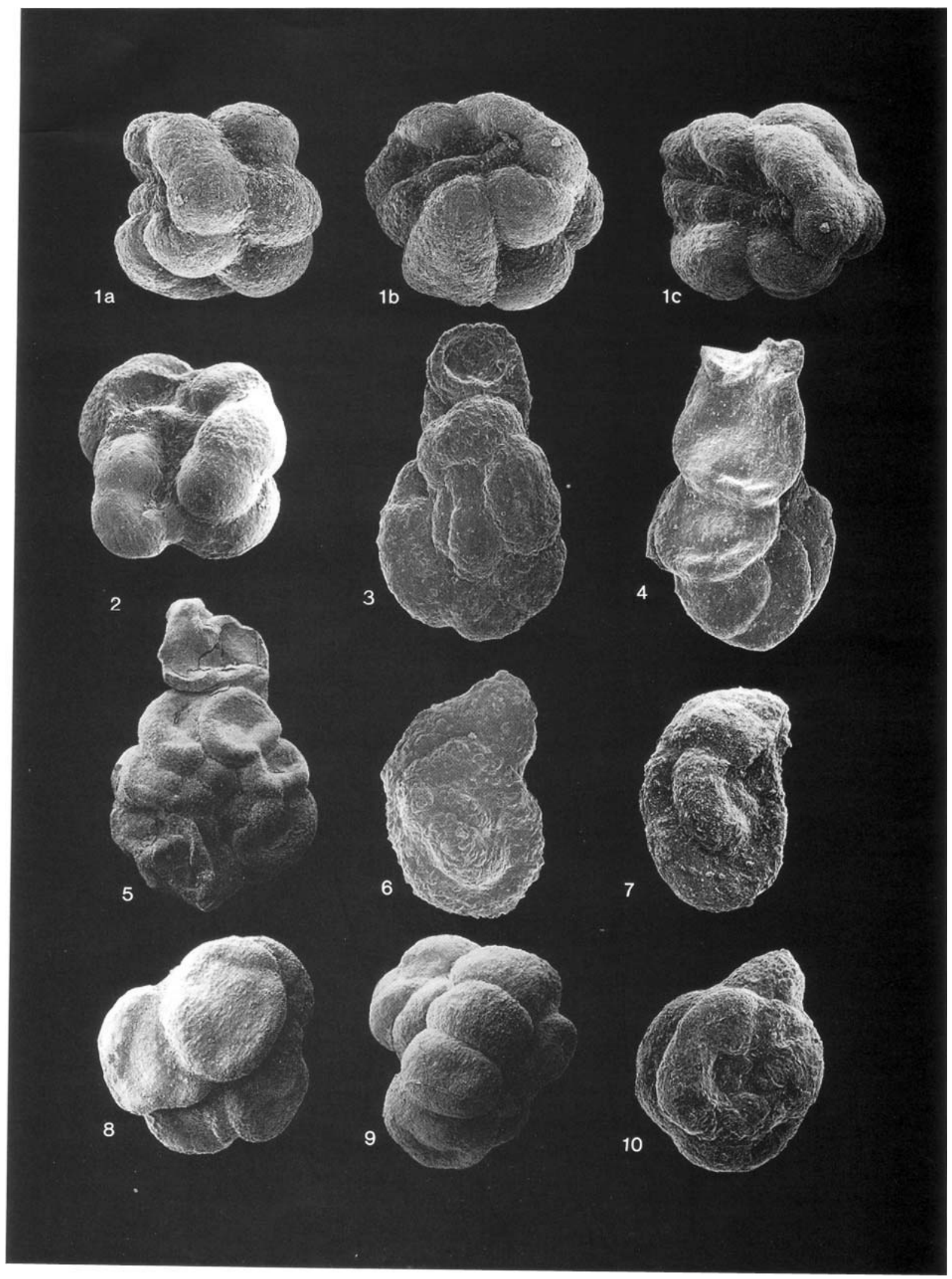

Plate 4 
Paratrochamminoides draco (Grzybowski, 1901)

(Pl. 3, fig. 8)

1901 Trochammina draco Grzybowski, p. 280, pl. 8, fig. 10 1993 Paratrochamminoides draco (Grzybowski); Kaminski \& Geroch: 277, pl. 16, fig. 5a-c

Paratrochamminoides gorayskii (Grzybowski, 1898)

(Pl. 4, figs 6-7)

1898 Ammodiscus gorayskii Grzybowski, p. 283, pl. 11, fig. 5 1993 Paratrochamminoides gorayskii (Grzybowski): Kaminski \& Geroch, 255, pl. 5, fig. 8a-d

Paratrochamminoides heteromorphus (Grzybowski, 1898)

(Pl. 4, figs 3-5)

1898 Trochammina heteromorpha Grzybowski: 286, pl. 11 , fig. 16 1993 Paratrochamminoides heteromorphus (Grzybowski); Kaminski \& Geroch, 258, pl. 7, figs 3a-5b

Paratrochamminoides irregularis (White, 1928)

(Pl. 4, fig. 8)

1928 Trochamminoides irregularis White: 307 , pl. 42 , fig. 1

1990 Paratrochamminoides irregularis (White); Kuhnt: 320; pl. 5, fig. 10

Paratrochamminoides mitratus (Grzybowski, 1901)

(Pl. 4, fig. 9)

1901 Trochammina mitrata Grzybowski, p. 280, pl. 8, fig. 3

1993 Paratrochamminoides mitratus (Grzybowski); Kaminski \&

Geroch: 278. pl. 16. figs 4a,b; 6a,b

Paratrochamminoides olszewskii (Grzybowski, 1898)

(PI. 4, fig. 10)

1898 Trochammina olszewskii Grzybowski: 298, pl. 11, fig. 6 1993 Paratrochamminoides olszewskii (Grzybowski); Kaminski \& Geroch: 257, pl. 7, figs la-2b

Paratrochamminoides uviformis (Grzybowski, 1901)

(Pl. 3, fig. 6)

1901 Trochammina uviformis Grzybowski: 281, pl. 8, figs 1-2 1993 Paratrochamminoides uviformis (Grzybowski); Kaminski \& Geroch: 278, pl. 16, figs 4a,b; 6a,b

Paratrochamminoides sp. 4

(Pl. 3, figs 10-11)

Test medium to large, coiling irregularly glomospiral, rounded inflated chambers with depressed sutures increasing rapidly in size after first whorl. The glomospiral coiling and rapidly enlarging chambers distinguish this species from $P$. acervulatus (Grzybowski, 1896).

Paratrochamminoides sp. 5.

(Pl. 4, figs $1 \mathrm{a}-2$ )

Specimens small, compact, quadrate in outline, possessing rounded chambers. Coiling changes abruptly and at $180^{\circ}$ angles, and is arranged around two orthogonal axes as in the genus Thalmannammina. Wall smooth, finely finished. Only a few specimens were found in our samples, but its distinctive mode of coiling sets this apart from all previously described species of Paratrochamminoides.

Psammosphaera irregularis (Grzybowski, 1896)

1896 Keramosphaera irregularis Grzybowski: 273, pl. 8, figs 12-13 1964 Psammosphaera irregularis (Grzybowski): Grün et al: 248, pl. 3. fig. 7

Recurvoides ef. imperfectus Hanzliková, 1965

1965 Recurvoides imperfectus Hanzliková: 38, text fig. 7

Recurvoides nucleolus (Grzybowski, 1898)

(Pl. 2, fig. 13)

1960 Recurvoides deflexiformis (Noth); Geroch: 52, pl. 5, fig. 6 1993 Recurvoides nucleolus (Grzybowski); Kaminski \& Geroch: 265, pl. 11, fig. $4 \mathrm{a}-\mathrm{d}$.

Recurvoides ex gr. gerochi Pflaumann, 1964

1960 Recurvoides sp. 1., Geroch: 52, pl. 3, fig. 13

1964 Recurvoides gerochi Pflaumann: 102-104, pl. 14, fig. 1 a-d
Recurvoides sp. 2

Large streptospiral test, relatively coarse grained, chambers increase rapidly in size.

Reophax elongatus Grzybowski, 1898

(Pl. 2, figs 7-8)

1898 Reophax elongatus Grzybowski: 279, pl. 10, figs 19-20

Reticulophragmium amplectens (Grzybowski, 1898)

(Pl. 2, fig. 12)

1898 Cyclammina amplectens Grzybowski: 292, pl. 12, figs 1-3

1993 Reticulophragmium amplectens (Grzybowski); Kaminski \& Geroch: 266, pl. 11, figs 5-7c

Rhabdammina annulata Grzybowski, 1896

1896 Rhabdammina annulata Grzybowski: 276, pl. 8, figs 8-9

1981 Reophax cf. subnodulosa Grzybowski; Liszka \& Liszkowa: p. 166, pl. 1, fig. 4a

Rhabdammina cylindrica (Glaessner, 1937)

1937 Rhabdammina cylindrica Glaessner: 354, pl. 1, fig. 1

Rhabdammina robusta (Grzybowski, 1898)

(Pl. 1, figs 2, 18)

1898 Dendrophrya robusta Grzybowski: 273, pl. 10, fig. 7

1993 Rhabdammina robusta (Grzybowki); Kaminski \& Geroch: 247, pl. 1, figs 7-9b, 16a,b

Rhizammina cf. indivisa Brady, 1884

1884 Rhizammina indivisa Brady: 277, pl. 29, figs 5-7

Rzehakina epigona (Rzehak, 1895)

(Pl. 1, fig. 16)

1895 Silicina epigona Rzehak: 214, pl. 6, fig. 1

Saccammina grzybowskii (Schubert, 1902)

1902 Reophax grzybowskii Schubert: 20, pl. 1, fig. 13

1993 Saccammina grzybowskii (Schubert); Kaminski \& Geroch: 248 , pl. 2, figs $1 \mathrm{a}-4 \mathrm{~b}$

Saccammina placenta (Grzybowski, 1898)

(Pl. 2, figs 1-2)

1898 Reophax placenta Grzybowski: 276-277, pl. 10, figs 9-10

1993 Saccammina placenta (Grzybowski); Kaminski \& Geroch: 249, pl. 2, figs 5-7

Subrenphax pseudoscalaris (Samuel, 1977)

1977 Reophax pseudoscalaria Samuel: 36, pl. 3, fig. 4a-b

1988 Subreophax pseudoscalaris (Samuel); Kaminski et al: 187, pl. 3 , figs 5-6

Subreophax scalaris (Grzybowski, 1896)

(Pl. 2, fig. 7)

1896 Reophax guttifera Brady var. scalaria Grzybowski: 277, pl. 8, fig. 26

1988 Subreophax scalaris (Grzybowski); Kaminski et al: 187, pl. 2, figs $16-17$

Trochamminoides dubius (Grzybowski, 1898)

(Pl. 3, figs 1-2)

1901 Ammodiscus dubius Grzybowski: 274, pl. 8, figs 12, 14

1970 Trochamminoides dubius (Grzybowski); Neagu: 38, pl. 2, fig. 20

Trochamminoides folius (Grzybowski, 1898)

1898 Trochammina folium Grzybowski, p. 288, pl. 11, figs 7-9

1993 Trochamminoides folius (Grzybowski); Kaminski \& Geroch: 261 , pl. 9, figs $1 \mathrm{a}-4 \mathrm{~b}$

Trochamminoides proteus (Karrer, 1866)

(Pl. 3, fig. 12)

1866 Trochammina proteus Karrer, pl. 1, fig. 8

1928 Trochamminoides proteus (Karrer); White: 308 , pl. 42, fig. 2

Trochamminoides septatus (Grzybowski, 1898)

(Pl. 3, fig. 9)

1898 Ammodiscus septatus Grzybowski: 283, pl. 11, fig. 1

1993 Trochamminoides septatus (Grzybowski): Kaminski \& Geroch:

255, pl. 5, fig. $9 \mathrm{a}-\mathrm{c}$ 


\section{Trochamminoides subcoronatus (Grzybowski, 1896)}

(Pl. 3, fig. 6)

1896 Trochammina subcoronata Grzybowski: 283-284, pl. 9, fig. $3 \mathrm{a}-\mathrm{c}$

1988 Trochamminoides subcoronatus (Graybowski); Kaminski et al: 192, pl. 4, fig. 19

Trochamminoides variolarius (Grzybowski, 1898)

(Pl. 3, fig. 5)

1898 Trochammina variolaria Grzybowski: 288, pl. 11, fig. 15

1993 Trochamminoides variolarius (Grzybowski): Kaminski \&

Geroch: 261 , pl. 9, figs 5a-6c

\section{ACKNOWLEDGEMENTS}

Field work was assisted by the German Research Council (DFG), project number WI-127/2, as part of the ALKAPECA project at the University of Tübingen. We are grateful to the Geological Survey of Morocco (Drs Bensaid \& Dahmani) for permission to work in the area. Drs Klaus Reicherter and Thomas Pletsch (University of Tübingen) helped collect samples. Jim Davy, Toby Stiles, George Dumitrescu, and Vaila Holbourn assisted with photography and drafting. Drs. W.A. Berggren (WHOI) and M.A. Charnock (SPT) kindly reviewed the manuscript. JDR acknowledges the support of an Advanced Course Studentship from the Natural Environment Research Council. This is contribution number 36 of the Deep-Water Agglutinated Foraminiferal Project.

\section{Manuscript received December 1993. Manuscript accepted June 1995.}

\section{REFERENCES}

Altenbach, A. V.. Unsöld, G. \& Walger, E. 1988. The hydrodynamic environment of Saccorhiza ramosa (Brady). Meyniana, 40: 119-132.

Alve, E. 1990. Variations in estuarine foraminiferal biofacies with diminishing oxygen conditions in Drammensfjord, SE Norway. In Hemleben, C.. Kaminski, M. A., Kuhnt, W., Scott, D. B. (Eds), Palaeocology, Biostratigraphy, Palaeoceanography and Taxonomy of Agglutinated Foraminifera, 661-694. NATO ASI Serics C. Mathematical and Physical Sciences, 327: Kluwer Academic Publishers, Dordrecht.

Barron, E. J. \& Peterson, W. H. 1990. Mid-Cretaceous Ocean Circulation: Results from model sensitivity studies. Palaeoceanography 5: 319-337.

Berggren, W. A. \& Kaminski, M. A. 1990. Abyssal Agglutinates: Back to Basics. In Hemleben, C., Kaminski, M. A., Kuhnt, W. \& Scot1, D. B. (Eds), Palaeoecology, Biostratigraphy, Palaeoceanography and Taxonomy of Agglutinated Foraminifera, 53-76, NATO ASI Series C, Mathematical and Physical Sciences, 327: Kluwer Academic Publishers, Dordrecht.

Berggren, W. A., Kent, D. V., Flynn, J. J. \& Van Couvering, J. A. 1985. Cenozoic geochronology. Geological Society of Anerica Bulletin, 96: 1407-1418.

Berggren, W. A. \& Olsson, R. K. 1986. North Allantic Mesozoic and Cenozoic Palaeobiogeography. In Vogt, P. R. \& Tucholke, B. E. (Eds), The Geology of North America, Volume $M$. The Western North Atlantic Region. 565-587. Geological Society of America.

Berry, E. W. 1928. The smaller foraminifera of the middle Lobitos shales of northwestern Peru. Eclogae Geologae Helvetiae, 21: $390-405$.

Bohrmann, (3. \& Stein, R. 1989. Biogenic silica at ODP Site 647 in the southern Labrador Sea: occurrence, diagenesis, and Palaeoccanographic implications. In Srivastava, S. P., Arthur, M., Clement, B. et al. Proceedings of the Ocean Drilling Program, Scientific Riesults, 105: 155-170.
Bolli, H. 1957. The genera Globigerina and Globorotalia in the Palaeocene-Lower Eocene Lizard Springs Formation of Trinidad, B. W. 1. I. US National Museum Bulletin, 215: 61-81.

Brady, H. B. 1879 . Notes on some of the reticularian Rhizopoda of the 'CHALLENGER' Expedition: Part I. On new or little known Arenaceous types. Quarterly Jominal of Microscopical Sciences, 19: $20-63$.

Brady, H. B. 1881. Notes on some of the reticularian Rhizopoda on the 'CHALI,ENGER' Expedition; Part III. Quarterly Joumal of Microscopical Sciences, 21: 31-71.

Brady, H. B. 1884. Report on the foraminifera dredged by H.M.S. CHALLENGER during the years 1873-1876. In Murray, J. (Ed.). Reports of the scientific resalts of the vovage of the H. M.S. Challenger. Zoology, 9: 1-814.

Charnock. M. A. \& Jones, R. W. 1990 . Agglutinated foraminifera from the Palaeogene of the North Sea. In Hemleben, C. Kaminski, M. A.. Kuhnt, W. \& Scott. D. B. (Eds), Palaeoecologv, Biostratigraphy, Palaeoceanography and Taxonomy of Agglutin ated Foraminifera. 139-244. NATO ASI Series C, Mathemalical and Physical Sciences, 327: Kluwer Academic Publishers, Dordrecht

Corliss, B. H. 1985. Microhabitats of benthic foraminifera within deep-sca sediments. Nature, 314: 435-438.

Corliss, B. H. \& Chen, C. 1988 . Morphotype patterns of Norwegian Sea deep-sea benthic foraminifera and ccological implications. Geology, 16: 716-719.

Corliss, B. H. \& Fois. E. 1991. Morphotype analysis of deep-sed benthic foraminifera from the northwest Gulf of Mexico. PALAIOS, 5: 589-605.

Cushman, J. A. \& Jarvis, P. W. 1928. Cretaccous foraminifera from Trinidad. Contributions from the Cushman Laboratory for Foraminiferal Research, 4: 85-103.

Dercourt. J., Zonenshain L. P., Ricou, L. E., Kazmin. V. G., Le Pichon, X., Knipper, A. L.. Grandjacquet, C., Sborshchikov, I. M., Boulin, J., Sorokhtin, O.. Geyssant, J., Lepvrier. C.. Biju-Duval, B., Sibuet, J.-C., Savostin, L. A., Westphal, M. \& Lauer, J.-P. 1985. Présentation de 9 cartes paléogéographiques au 1/20. 000.000 s'étendant de l'Atlantique au Pamir la période du Lias à l'Actuel. Bulletin de la Société géologique de France, (8'), 5 : $637-652$

Didon, J., Durand-Delga, M. \& Kornprobst, J. 1973. Homologies géologiques entre les deux rives du détroit de Gibraltar. Bulletin de la Société géologique de France (7), 15: 77-105.

Durand-Delga, M. 1972. La courbure de Gibraltar, extrémité occidentale des chaines alpines, unit l'Europe et l'Afrique. Eclogae Geologae Helvetiae, 65: 267-278.

Dylązanka, M. 1923. Warstwy inoceramowe z łomu w Szymbarku koło Gorlic. Rocznik Polskiego Towarzyswa Geologicznego, 1: $36-80$.

Geroch. S. 1960. Microfaunal assemblages from the Cretaceous and Palaeogene Silesian Unit in the Beskid Slaski Mts. (western Carpathians). Biuletyn Instytutu Geologicznego, Wars/awa, 153: $7-138$.

Geroch. S. \& Nowak, W. 1984. Proposal of Zonation for the late Tithonian - late Eocenc, based upon arcnaccous foraminifera Irom the outer Carpathians. Poland. In Oertli, H. (Ed.), Benthos 8.3; 2nd International Symposium on Benthic Foraminifera Palt (France), April 11-15, 1983, 225-239. Elf Aquitaine, ESSO REP and TOTAL C.FP. Pau \& Bourdcaux.

Glaessner, M. F. 1937. Studien über Foraminiferen aus der Kreide und dem Tertiär des Kaukasus; 1. Die Foraminileren der ältesten Tertiärschichten des Nordwest-Kaukas. Problems of Palaeontology, Moscow, 2-3: 349-408.

Gradstein, F. M. \& Berggren, W. A. 1981. Flysch-lype agglutinated foraminifera and the Maestrichtian to Palaeogene history of the Labrador and North Seas. Marine Micropalaeontology, 6: $211-268$.

Grün, W.. Lauer, G., Niedermeyer, G. \& Schnabel, W. 1964. Die Kreide-Tertiar Grenze im Wienerwaldflysch bei Hochstrass/Niederosterreich. Verhandlungen der Geologischen Bundesanstalt, Wien, 2: 226-283.

Grzybowski, J. 1896. Otwornice czerwonych iłów z Wadowic. 
Rozprawy Akademii Umiegjetności w Krakowie, Wydział Matematyczno-Przyrodniczy, Kraków, ser. 2, 30: 261-308.

Grzybowski, J. 1898. Otwornice pokładów naftonośnych okolicy Krosna. Rozprawy Akademii Umiejetności w Krakowie, Wydział Matematyczno-Przyrodniczy, Kraków, ser. 2, 33: 257-305.

Grzybowski, J. 1901. Otwornice warstw inoceramowych okolicy Gorlic. Rozprawy Akademii Umiejetności w Krakowie, Wydział Matematyczno-Przyrodniczy, Kraków, ser. 2, 41: 219-288.

Hanzliková, E. 1965. Stratigraphie der Kreide und des Palaogens der flyschzone der Westkarpaten. Geologicky Sbornik, 16: 33-64.

Herguera, J. \& Berger, W. H. 1991. Palacoproductivity from benthic foraminiferal abundance: Glacial to postglacial change in the west-equatorial Pacific. Geology, 19: 1173-1176.

Jones, J. P. \& Parker, W. K., 1860. On the Rhizopodal fauna of the Mediterranean compared with that of the Italian and some other Tertiary deposits. Quarterly Journal of the Geological Society of London, 16: 292-307.

Jurkiewicz, H. 1960. Otwornice z łupków czarnorzeckich wschodniej części jednostki sląskiej. Rocznik Polskiego Towarzystwa Geologicznego 30: 333-345.

Jurkiewicz, H. 1967. Foraminifers in the sub-Menilitic Palaeogene of the Polish Middle Carpathians. Biuletyn Instytutu Geologicznego, Warszawa, 210: 5-116.

Kaminski, M. A. 1985. Evidence for control of abyssal agglutinated community structure by substrate disturbance: Results from the HEBBLE Area. Marine Geology, 66: 113-131.

Kaminski, M. A. 1991. Patterns and process of biotic impoverishment in deep-water agglutinated foraminiferal faunas across the Paleocene/Eocene boundary: an example of multiple causes and effects? IGCP Project 308 Conference, Brussels, Program and Abstracts.

Kaminski, M. A. \& Geroch. S. 1993. A revision of foraminiferal species in the Grzybowski Collection. In Kaminski. M. A. Geroch, S. \& Kaminski, D. G. (Eds), The origin of applied micropalaeontology: the school of Józef Grzybowski. Grzybowski Foundation Special Publication, 1: 239-323.

Kaminski, M. A., Gradstein, F. M. \& Berggren, W. A. 1989. Palaeogene benthic foraminifer biostratigraphy and Palaeoccology at Site 647, southern Labrador Sea. In Srivastava, S. P. Arthur, M. A. \& Clement, B. et al. , Proceedings of the Ocean Drilling Program, Scientific Results, 105: 705-730.

Kaminski, M. A., Gradstein, F. M., Berggren, W. A., Geroch, S. \& Beckmann, J.-P. 1988. Flysch-type agglutinated foraminiferal assemblages from Trinidad: taxonomy, stratigraphy and Palaeobathymetry. In Rögl, F. \& Gradstein, F. M. (Eds), Second Workshop on Agglutinated Foraminifera, Vienna 1986, Proceedings. Abhandlungen der Geologischen Bundesanstalt, 41: $155-227$.

Kaminski, M. A., Gradstein, F., Goll, R. F. \& Greig, D. 1990, Biostratigraphy and Palacoecology of deep-water agglutinated foraminifera at ODP Site 643, Norwcgian-Greenland Sea. In Hemleben, C., Kaminski, M. A., Kuhnt, W., Scott, D. B. (Eds), Palaeoecology, Biostratigraphy, Palaeoceanography and Taxonomy of Agglutinated Foraminifera, 345-386, NATO ASI Series C. Mathematical and Physical Sciences, 327, Kluwer Academic Publishers, Dordrecht.

Karrer, F. 1866. Über das auftreten von Foraminiferen in den alteren Schichten des Wiener Sandsteins. Sitzungsbereichte der Kaiserlichen Akademie der Wissenschaften Wien. MathematischNaturwissenschaftliche Classe, 52, (Jahrg 1865), Abt. 1, Heft 9. 121-193.

Katz, M. E. \& Miller, K. G. 1991. Early Palaeogene benthic foraminiferal asscmblages and stable isotopes in the Southern Ocean. Proceedings of the Ocean Drilling Program, Scientific Results, 114: 481-512.

Kennett, J. P. \& Stott, L. D. 1991. Abrupt deep-sea warming, Palaeoceanographic changes and benthic extinctions at the end of the Palaeocene. Nature, 353: 225-229.

Kuhnt, W. 1990. Agglutinated forminifera of Western Mediterranean Upper Cretaceous pelagic Limestones (Umbrian Appenines, Italy, and Betic Cordillera, Southern Spain). Micropaleontology 36: 297-330.

Kuhnt, W. \& Kaminski, M. A. 1989. Upper Cretaceous deep-water agglutinated benthic foraminifcral asscmblages from the Western Meditcrranean and adjacent areas. In Wiedmann. J. (Ed.) Cretaceous of the Western Tethys. Proceedings of the 3rd International Cretaceous Symposium, Tiibingen, Schweizerbart'sche Verlagsbuchahandlung, 91-120.

Linke, P. \& Lutze, G. 1993. Microhabitat preferences of benthic foraminifera-A static concept or dynamic adaptation to optimize food acquisition? Marine Micropalaeontology, 20: 215-234.

Liszka, S. \& Liszkowa, J. 1981. Revision of J. Grzybowski's paper (1896) 'Foraminifera of the red clays from Wadowice'. Rocznik Polskiego Towarzystwa Geologicznego, 51: 153-208.

Majzon, L. 1943. Adatok egyes Kárpátaljai Flisrétegekhez, tckintettel a Globotruncanákra. Beiträge zur Kenntniss ciniger Flysch-Schichten des Karpaten-Vorlandes mit Rücksicht auf die Globotruncanen. A magyar Királyi Földtani Intézet, Évkönyve. 37: $1-170$.

Maslakova, N. I. 1955. Stratigrafiya i fauna melkikh foraminifer Palacogenovykh otlozhenii Vostochnykh Karpat. Materialy po Biostratigrafi zapadnykh oblastii Ukrainskoi SSR, Moskva, $5-132$.

Miller, K. G., Fairbanks, R. G. \& Mountain, G. S. 1987. Tertiary oxygen isotope synthesis, sea level history, and continental margin erosion. Palaeoceanography, 2: $1-19$.

Miller, K. G., Gradstein, F. M. \& Berggren, W. A. 1982. Late Cretaceous to early Tertiary agglutinated benthic foraminifera in the Labrador Sea, Micropalaeontology, 28: $1-30$.

Miller, K. G., Janecek, T. R., Katz, M. E. \& Keil, D. J. 1987. Abyssal circulation and benthic foraminiferal changes near the Palaeocene/Eocene boundary. Palaeoceanography 2: 741-761,

Morgicl, J. \& Olszewska, B. 1981. Biostratigraphy of the Polish External Carpathians based on agglutinated foraminifera. Micropalaeontology, 27: 1-30.

Morgiel, J. \& Olszewska, B. 1982. Uniformity of the Tethyan faunas from Cretaceous and Palaeogene as shown by foraminifera from Morocco and Polish Flysch Carpathians. Cahiers de Micropaléontologie, 3: 45-53.

Morgicl, J. \& Szymakowska, F. 1978. Stratygrafia Palaeocenu i Eocenu jednostki skolskiej. Biuletyn Instytutu Geologicznego. 310: $39-71$.

Mountain, G. S. \& Miller, K. G. 1992. Seismic and geologic evidence for early Palaeogene deepwater circulation in the western North Atlantic. Palaeoceanography 7: 423-439.

Myatlyuk, E. V. 1970. Foraminifery flishevykh otlozhenii vostochnykh Karpat (Mel-Palaeogen). Trudy Vsesoyuznogo Natuchno-Issledovatel'skogo Geologorazvedochnogo Instituta VNIGRI, Leningrad, 282: 1-225.

Neagu, T. 1964. Large size agglutinated foraminifera from the Carpathian of Rumania. Rocznik Polskiego Towarzystwa Geologicznego, 34: 579-588.

Neagu, T. 1970. Micropalacontological and stratigraphical study of the Upper Cretaceous deposits between the upper valleys of the Buzau and Riul Negru Rivers (Eastern Carpathians). Memorii Institutul Geologic, Bucarest, 12: 7-109.

Olszewska, B. \& Smagowicz, M. 1977. Porownanie podziałów biostratygraficznych górnej kredy i Palacogenu jednostki dukielskicj na podstawie otwornic planktonicznych i nannoplantonu wapiennego [A comparison of Upper Cretaceous and Palaeogene biostratigraphic schemes based on planktonic foraminifera and nannofossils|. Przeglad Geologiczny, 7: 359-363.

Owen, R. M. \& Rea, D. K. 1985. Sea floor hydrothermal activity links climate to tectonics: The Eocene greenhouse. Science, 227: $166-169$

Pak, D. K. \& Miller, K. G. 1992. Palaeocene to Eocene benthic foraminiferal isotopes and assemblages: implications for deepwater circulation. Palaeoceanography, 7: 405-422.

Pedersen. T. F.. Pickering. M, Vogcl, J. S., Southon, J. N. \& Nelson, D. E. 1988. The response of benthic foraminifera to productivity cycles in the eastern equatorial Pacific: faunal and geochemical constraints on glacial bottom water oxygen levels. Palaeoceanography, 3: 157-168.

Pflaumann, U. 1964. Geologisch-mikropalaontologische Untersuchungen in der Flysch-Oberkreide zwischen Wertach und 
Palaeocene-Eocene deep water agglutinated forminifera from the Numidian Flysch

Chiemsee in Bayern. Inaugural dissertation. Ludwig Maximilian Universitat. Munchen.

Reuss, A. E. 1845. Die Versteinerungen der böhmischen Kreideformation. Abtheilung 1, E. Schweizerbartsohne Verlagsbuchhandlung. Stuttgart.

Rögl. F., Fuchs. R.. Schnabel, W.. Seifert. P. \& Wagner, L. 1986. Excursion Guide to the 2nd IWAF Excursion in Austria 1986. Second International Workshop on Agglutinated Foraminifera. Abstracts, Program and Excursion Guide. 60--92. H. Peter Press. Strasshof, Austria.

Rzehak, A. 1895. Über einige merkwurdige Foraminiferen aus dem Österrsichischen Tertiär. Annalen des $K . K$. Naturhistorisches Hofmutseum. Wien, 10: 213-230.

Samuel, O. 1977. Agglutinated foraminifers from Palaeogene flysch formations in West Carpathians of Slovakia. Západné Karpaty, série Palaeontológie, 2-3: 7-70.

Schnitker, D. 1979. Cenozoic deep water benthic foraminifers, Bay of Biscay. In Montadert, L., Roberts. D. G., et al. , Initial Reports of the Deep Sea Drilling Project, 48: 377-414. Washington (U. S. Government Printing Olfice).

Schubert. R. J, 1902. Neue und interessante Foraminiferen aus dem südtiroler Altteriär. Beiträge zur Paläontologie und Geologie Österretch-Ungarns und des Orients, 14: 9-26.

Shackleton, N. J. 1986. Palaeogene stable isotope events. Palaeogeography, Palaeoclimatology, Palaeoecology, 57: 91-101.

Stott, L. D. 1992. Higher temperatures and lower oceanic $\mathrm{pCO}_{2}: \mathrm{A}$ climatic enigma at the end of the Palacocene epoch. Palaeoceanography, 7: 395-404.

Suter, G. 1980. Carte géologique de la chaine rifaine, echelle
1/500000. Notes et Mémoires du Service Géologique du Maroc: 245 .

Thomas, E. \& Shackleton, N. J. 1991. Deep-sea circulation through the Cacnozoic. Britain in the Ocean Drilling Program 1991 (abstracts).

Tjalsma. R. C. 1977. Cenozoic foraminifera from the south Atlantic. In Barker, P. F., Dalziel, I. W. D. et al. . Initial Reports of the Deep Sea Drilling Project, 36: 493-518. Washington (U. S. Government Printing Office).

Tjalsma, R. C. \& Lohmann, G. P. 1983. Palaeocene-Eocene bathyal and abyssal benthic formainifera from the Atlantic Ocean. Micropalaeontology Special Publication, 4: 1-90.

Verdenius, J. G. \& Van Hinte, J. E. 1983. Central NorwegianGreenland Sea: Tertiary arenaccous foraminifera, biostratigraphy and environment. Proceedings of the First Workshop Arenenaceous Foraminifera, 7-9 Sept. 1981. Continental Shelf Institute Publication, 108: 173-224.

White, M. P. 1928. Some index foraminifera from the Tampico Embayment area of Mexico (Part 2). Journal of Palaeontology, 2: 280-317.

Wildi. W. 1983. La chaîne tello-rifaine (Algéric, Maroc, Tunisie): Structure. stratigraphic et évolution du Trias au Miocène. Revue de Géologie Dynamique et de Géographie Physique, 24: 201-297.

Winkler, W. 1984. Rhabdammina-fauna: What relation to turbidites? Evidence from the Gurnigel-Schlieren Flysch. In Oertli, H. J. (Ed.), Benthos 183; 2nd International Symposium on Benthic Foraminifera Pat (France), April 11-15, 1983,611617 Elf Aquitaine. ESSO REP and TOTAL CFP, Pau \& Bourdeaux. 